\title{
Study Design and Analytical Results Used to Evaluate a Surface-Water Point Sampler for Volatile Organic Compounds
}

By Michael J. Halde, Gregory C. Delzer, and John S. Zogorski

Open-File Report 98-651 
U.S. Department of the Interior

Bruce Babbitt, Secretary

U.S. Geological Survey

Charles G. Groat, Director

The use of firm, trade, and brand names in this report is for identification purposes only and does not constitute endorsement by the U.S. Geological Survey.

Rapid City, South Dakota: 1999

For additional information write to:

\section{District Chief}

U.S. Geological Survey

1608 Mt. View Road

Rapid City, SD 57702

Copies of this report can be purchased from:

U.S. Geological Survey

Branch of Information Services

Box 25286

Denver, CO 80225-0286 


\section{FOREWORD}

The mission of the U.S. Geological Survey (USGS) is to assess the quantity and quality of the earth resources of the Nation and to provide information that will assist resource managers and policymakers at Federal, State, and local levels in making sound decisions. Assessment of water-quality conditions and trends is an important part of this overall mission.

One of the greatest challenges faced by waterresources scientists is acquiring reliable information that will guide the use and protection of the Nation's water resources. That challenge is being addressed by Federal, State, interstate, and local water-resource agencies and by many academic institutions. These organizations are collecting water-quality data for a host of purposes that include: compliance with permits and water-supply standards; development of remediation plans for a specific contamination problem; operational decisions on industrial, wastewater, or watersupply facilities; and research on factors that affect water quality. An additional need for water-quality information is to provide a basis on which regional and national-level policy decisions can be based. Wise decisions must be based on sound information. As a society we need to know whether certain types of water-quality problems are isolated or ubiquitous, whether there are significant differences in conditions among regions, whether the conditions are changing over time, and why these conditions change from place to place and over time. The information can be used to help determine the efficacy of existing waterquality policies and to help analysts determine the need for and likely consequences of new policies.

To address these needs, the Congress appropriated funds in 1986 for the USGS to begin a pilot program in seven project areas to develop and refine the National Water-Quality Assessment (NAWQA) Program. In 1991, the USGS began full implementation of the program. The NAWQA Program builds upon an existing base of water-quality studies of the USGS, as well as those of other Federal, State, and local agencies. The objectives of the NAWQA Program are to:

- Describe current water-quality conditions for a large part of the Nation's freshwater streams, rivers, and aquifers.
- Describe how water quality is changing over time.

- Improve understanding of the primary natural and human factors that affect water-quality conditions.

This information will help support the development and evaluation of management, regulatory, and monitoring decisions by other Federal, State, and local agencies to protect, use, and enhance water resources.

The goals of the NAWQA Program are being achieved through ongoing and proposed investigations of 59 of the Nation's most important river basins and aquifer systems, which are referred to as Study Units. These Study Units are distributed throughout the Nation and cover a diversity of hydrogeologic settings. More than two-thirds of the Nation's freshwater use occurs within the 59 Study Units and more than two-thirds of the people served by public watersupply systems live within their boundaries.

National synthesis of data analysis, based on aggregation of comparable information obtained from the Study Units, is a major component of the program. This effort focuses on selected water-quality topics using nationally consistent information. Comparative studies will explain differences and similarities in observed water-quality conditions among study areas and will identify changes and trends and their causes. The first topics addressed by the national synthesis are pesticides, nutrients, volatile organic compounds, and aquatic biology. Discussions on these and other waterquality topics will be published in periodic summaries of the quality of the Nation's ground and surface water as the information becomes available.

This report is an element of the comprehensive body of information developed as part of the NAWQA Program. The program depends heavily on the advice, cooperation, and information from many Federal, State, interstate, Tribal, and local agencies and the public. The assistance and suggestions of all are greatly appreciated.

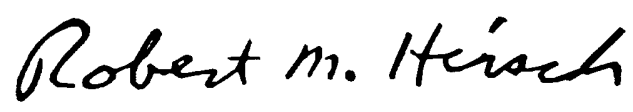

Robert M. Hirsch Chief Hydrologist 



\section{CONTENTS}

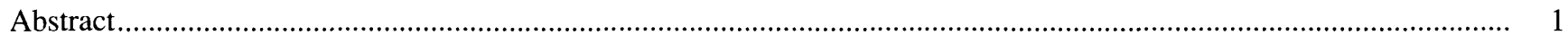

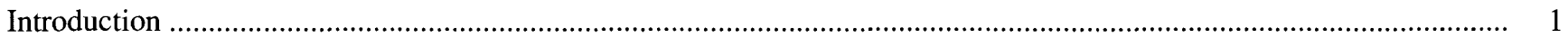

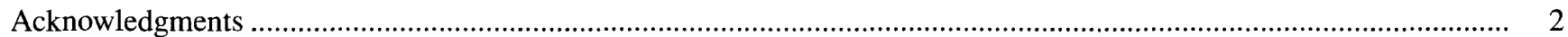

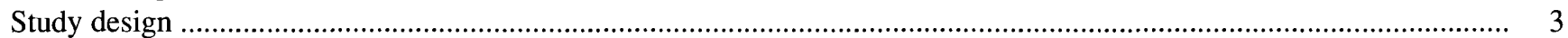

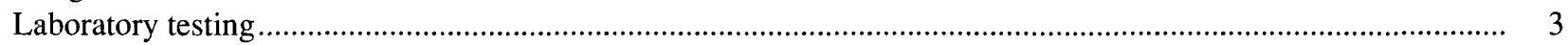

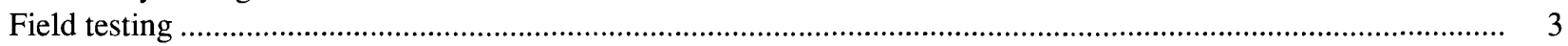

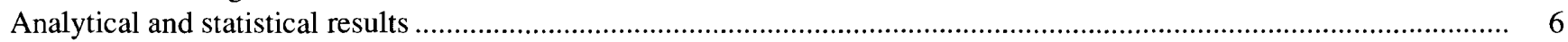

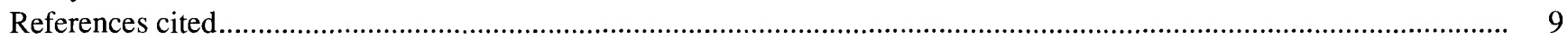

\section{ILLUSTRATIONS}

1. Photograph showing surface-water point sampler evaluated for collection of volatile organic compounds and component parts/related items

2. Graphical comparison of concentrations of 87 volatile organic compounds (VOCs) in samples

collected by VOC point sampler with concentrations in samples collected by glass-siphon

sampler during laboratory testing

3. Graphical comparison of concentrations of 87 volatile organic compounds (VOCs) in samples

collected by VOC point sampler with concentrations in samples collected by hand-dipping

method during field testing ......

\section{TABLES}

1. Volatile organic compounds analyzed by the U.S. Geological Survey National

Water-Quality Assessment Program

2. Results of replicate-sample analysis for volatile organic compounds (VOCs) during

laboratory and field testing of selected sampling equipment

3. Results of quality-control sample analysis for volatile organic compounds during laboratory and field testing of selected surface-water sampling equipment

\section{CONVERSION FACTORS}

\begin{tabular}{rll}
\hline Multiply & By & To obtain \\
\hline microgram per liter $(\mu \mathrm{g} / \mathrm{L})$ & 1.0 & part per billion \\
\hline
\end{tabular}

Temperature can be converted to degrees Celsius $\left({ }^{\circ} \mathrm{C}\right)$ or degrees Fahrenheit $\left({ }^{\circ} \mathrm{F}\right)$ by the following equations:

$$
\begin{aligned}
& { }^{\circ} \mathrm{C}=\left({ }^{\circ} \mathrm{F}-32\right) / 1.8 \\
& { }^{\circ} \mathrm{F}=\left(1.8 \times{ }^{\circ} \mathrm{C}\right)+32
\end{aligned}
$$




\title{
Study Design and Analytical Results Used to Evaluate a Surface-Water Point Sampler for Volatile Organic Compounds
}

\author{
By Michael J. Halde, Gregory C. Delzer, and John S. Zogorski
}

\section{ABSTRACT}

The most common technique used to sample streams for volatile organic compounds (VOCs) is dipping volatile organic analysis (VOA) vials by hand midstream. This technique does not assure that samples are collected in a consistent manner. A point sampler was designed to collect samples for the U.S. Geological Survey National WaterQuality Assessment (NAWQA) Program in surface water in a uniform and consistent manner nationwide. This report documents the study design used to evaluate the VOC point sampler, as well as comparative data from glass-siphoning and hand-dipping methods used in the laboratory and field, respectively. Quality-control data collected during the evaluation, specifically source-solution blanks, canister blanks, equipment blanks, and field blanks, also are presented.

The study indicates that the VOC point sampler collects samples in a representative manner, as compared to the glass-siphoning and handdipping methods. The relative standard deviation for replicate samples collected by the VOC point sampler was less than 10 percent for 57 of 73 VOCs calculated, indicating a high degree of sample reproducibility. Analyte loss was found to be negligible based, in part, on a comparison of laboratory data to expected recovered concentrations. Furthermore, the cleaning protocol was found to be effective in eliminating any contamination of water samples from the point sampler.

\section{INTRODUCTION}

Ground water has been sampled for the analysis of volatile organic compounds (VOCs) by the U.S. Geological Survey (USGS) National Water-Quality Assessment (NAWQA) Program since 1993. To understand the occurrence of VOCs in other components of the hydrologic cycle, the NAWQA Program began sampling small urban streams for VOCs in 1996. Prior to NAWQA's national emphasis on VOCs, little work had been done within the USGS on VOC field methods or sampling equipment for collecting VOCs from surface water. The most common technique used to sample streams for VOCs is dipping volatile organic analysis (VOA) vials by hand midstream. Consequently, the USGS did not have specific guidelines or a proven sampler to collect VOC samples from surface water.

To collect VOC samples from surface water in a uniform and consistent manner nationwide, a surfacewater VOC point sampler was designed by the USGS and Wildlife Supply Company (Wildco) located in Saginaw, Michigan. The sampler (fig. 1) is manufactured by Wildco and is constructed of stainless steel and refrigeration-grade copper. The sampler was designed to collect a sample intended for VOC analysis at a single point in shallow urban streams. The VOC point sampler currently (1998) is being used by NAWQA's study units to collect samples from about 10 urban streams (Lopes and Price, 1997). Guidance on the proper use of the sampler in the field has been developed and documented by Shelton (1997).

The purposes of this report are to: (1) document the study design used to evaluate the surface-water VOC point sampler and (2) report the analytical results. This report documents the analytical data 
determined for laboratory and field studies to evaluate the point sampler for sample reproducibility, VOC loss, and sample contamination.

\section{ACKNOWLEDGMENTS}

Many people have assisted with the development, design, and testing of the VOC point sampler. In particular, we gratefully appreciate the help of USGS employees Ronald E. Rathbun, Larry R. Shelton,
Thomas J. Lopes, Bruce D. Lindsey; Dr. James F. Pankow, Oregon Graduate Institute of Science and Technology in Beaverton, Oregon; and Jason Love, graduate student of the South Dakota School of Mines and Technology in Rapid City, South Dakota. The VOC analysts at the USGS NWQL including Brooke F. Connor, Donna L. Rose, Sonja R. Abney, Lucinda K. Murtagh, and Mary C. Noriega, are acknowledged for their continued involvement and suggestions in USGS VOC studies.

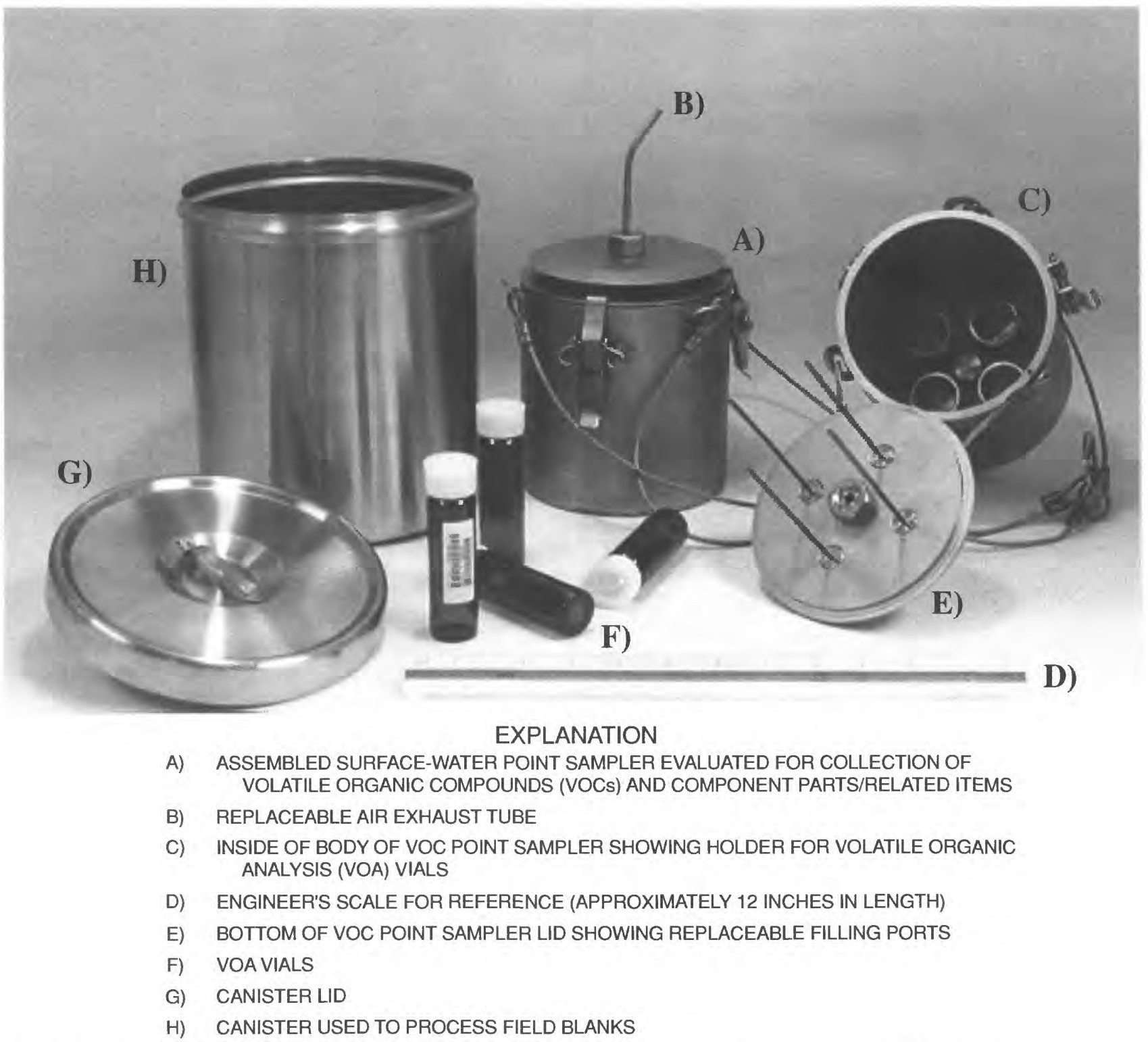

Figure 1. Surface-water point sampler evaluated for collection of volatile organic compounds and component parts/related items. 


\section{STUDY DESIGN}

This study was designed to verify the performance of the VOC point sampler. Sample reproducibility, analyte loss, and sample contamination were evaluated using sequential replicate samples collected by the VOC point sampler from a water matrix known to contain VOCs. Concurrent samples were collected with the VOC point sampler and also by siphoning through a glass bore tube during laboratory testing or hand dipping VOA vials during field testing. The samples were collected from a stainless-steel reservoir during laboratory testing and from a stream during field testing. Equipment blanks and field blanks were collected at prescribed steps of the study to determine whether equipment-cleaning protocols adequately removed VOCs from the VOC point sampler. Each time the equipment was cleaned, the equipmentcleaning protocol described by Shelton (1997) was followed.

The 87 VOCs analyzed by the USGS National Water-Quality Laboratory (NWQL) in Arvada, Colorado, for the NAWQA Program and this study are listed in table 1. Analytes are divided into two groups-NAWQA target analytes ( 55 compounds) and other analytes (32 compounds). The compounds 1,3and 1,4-dimethylbenzene are reported as separate target analytes in table 1, however, the NWQL reports the sum of the concentration of these two compounds because they co-elute during analysis. NAWQA target analytes were selected for emphasis in the NAWQA Program because of their known human-health and (or) aquatic-life concern or because of their high frequency of occurrence in surface water and ground water (John Zogorski, USGS, written commun., 1994). The "other analytes" were selected because they are on the U.S. Environmental Protection Agency's list for analysis using their revised method for drinking-water samples (Connor and others, 1998).

\section{Laboratory Testing}

Laboratory testing was done to provide controlled conditions under which the VOC point sampler could be evaluated. The VOC point sampler and a glass siphon were cleaned and wrapped in aluminum foil until sampling began. Three blank samples were collected using the VOC point sampler at the start of the laboratory testing prior to collecting samples known to contain VOCs. The three blank samples consisted of a source-solution blank, an initial canister blank, and an initial equipment blank. The source- solution blank was collected to determine if VOCs were present in the NWQL volatile-grade blank water. The initial canister blank was collected to determine if the canister, from which the equipment blank was collected, was contaminated with VOCs. The initial equipment blank was collected to characterize the condition of the VOC point sampler prior to collection of laboratory samples. Blank samples were collected according to methods described by Mueller and others (1997). Following quality-control sampling, replicate sampling was done in the laboratory from a reservoir.

A 115-liter stainless-steel reservoir located under a fume hood was filled with tap water, kept constant at $20^{\circ}$ Celsius, and stirred with a mixer for 24 hours. The reservoir was then spiked with 75 VOCs and mixed for 5 minutes. Concentrations of approximately $0.3 \mu \mathrm{g} / \mathrm{L}$ were spiked for 59 compounds. Fifteen VOCs were spiked to achieve a concentration of approximately $1.2 \mu \mathrm{g} / \mathrm{L}$. Trans-1,4-dichloro-2butene was spiked to $3.0 \mu \mathrm{g} / \mathrm{L}$ (table 2 at the end of this report). Only 75 of the 87 analytes listed in table 1 were added because a previously prepared VOC mix was used. The mixer was then turned off, and seven replicate samples were collected concurrently from the spiked reservoir with the VOC point sampler and glass siphon, under quiescent conditions. Both the VOC point sampler and glass siphon were cleaned between each replicate sample. After all replicate samples were collected, the samplers were cleaned again, and a final canister and a final equipment blank were collected with the VOC point sampler.

To test the effectiveness of the cleaning protocol, the VOC point sampler was soaked in a solution of 75 VOCs (each at a concentration of approximately $80 \mu \mathrm{g} / \mathrm{L}$ ) for 3.5 minutes. The sampler was then cleaned, and a high-concentration canister blank and a high-concentration equipment blank were collected.

\section{Field Testing}

Field testing was done to determine how the point sampler would perform under actual environmental conditions. Field testing was conducted during May 29 and 30, 1996, at Cedar Run, a spring-fed stream in Harrisburg, Pennsylvania. The spring was contaminated by a leaking underground storage tank and has measurable concentrations of gasoline-related VOCs and chlorinated VOCs. Prior to sample collection, the VOC point sampler was cleaned. Two blank samples were collected using the VOC point sampler prior to collection of samples from the stream known to contain VOCs. The two blank samples 
Table 1. Volatile organic compounds analyzed by the U.S. Geological Survey National Water-Quality Assessment Program

[Compounds are identified by the following: PCODE, U.S. Geological Survey parameter code; CAS no., Chemical Abstract Services number; IUPAC, International Union of Pure and Applied Chemistry; *, not included in spiking solution]

\begin{tabular}{|c|c|c|c|c|c|}
\hline PCODE & CAS no. & $\begin{array}{l}\text { IUPAC compound name } \\
\text { (chemical formula) (common name(s)) }\end{array}$ & PCODE & CAS no. & $\begin{array}{l}\text { IUPAC compound name } \\
\text { (chemical formula) (common name(s)) }\end{array}$ \\
\hline \multicolumn{6}{|c|}{ Target analytes } \\
\hline 32101 & $75-27-4$ & $\begin{array}{l}\text { Bromodichloromethane }\left(\mathrm{CHBrCl}_{2}\right) \\
\text { (dichlorobromomethane) }\end{array}$ & 34704 & $10061-01-5$ & $\begin{array}{l}\text { cis-1,3-Dichloropropene }\left(\mathrm{C}_{3} \mathrm{H}_{4} \mathrm{Cl}_{2}\right) \\
\quad((\mathrm{Z}) \text {-1,3-dichloropropene })\end{array}$ \\
\hline 34413 & $74-83-9$ & $\begin{array}{l}\text { Bromomethane }\left(\mathrm{CH}_{3} \mathrm{Br}\right) \\
\text { (methyl bromide) }\end{array}$ & 77135 & $95-47-6$ & $\begin{array}{l}\text { 1,2-Dimethylbenzene }\left(\mathrm{C}_{8} \mathrm{H}_{10}\right) \\
\quad(o \text {-xylene })\end{array}$ \\
\hline 77342 & $104-51-8$ & $\begin{array}{l}n \text {-Butylbenzene }\left(\mathrm{C}_{10} \mathrm{H}_{14}\right) \\
\quad \text { (1-phenylbutane) }\end{array}$ & 85795 & $108-38-3$ & $\begin{array}{l}\text { 1,3-Dimethylbenzene }\left(\mathrm{C}_{8} \mathrm{H}_{10}\right) \\
(m \text {-xylene }) \text { and }\end{array}$ \\
\hline 39175 & $75-01-4$ & $\begin{array}{l}\text { Chloroethene }\left(\mathrm{C}_{2} \mathrm{H}_{3} \mathrm{Cl}\right) \\
\quad \text { (vinyl chloride) }\end{array}$ & 50004 & $637-92-3$ & $\begin{array}{l}\text { 2-Ethoxy-2-methylpropane }\left(\mathrm{C}_{6} \mathrm{H}_{14} \mathrm{O}\right) \\
\text { (ethyl tert-butyl ether, ETBE) }\end{array}$ \\
\hline 34418 & $74-87-3$ & $\begin{array}{l}\text { Chloromethane }\left(\mathrm{CH}_{3} \mathrm{Cl}\right) \\
\text { (methyl chloride) }\end{array}$ & 34371 & $100-41-4$ & $\begin{array}{l}\text { Ethylbenzene }\left(\mathrm{C}_{8} \mathrm{H}_{10}\right) \\
\quad \text { (phenylethane) }\end{array}$ \\
\hline 82625 & $96-12-8$ & $\begin{array}{l}\text { 1,2-Dibromo-3-chloropropane }\left(\mathrm{C}_{3} \mathrm{H}_{5} \mathrm{Br}_{2} \mathrm{Cl} \text { ) }\right. \\
\text { (dibromochloropropane, } \mathrm{DBCP})\end{array}$ & 39702 & $87-68-3$ & $\begin{array}{l}\text { 1,1,2,3,4,4-Hexachloro-1,3-butadiene } \\
\quad\left(\mathrm{C}_{4} \mathrm{Cl}_{6}\right) \text { (hexachlorobutadiene) }\end{array}$ \\
\hline 32105 & $124-48-1$ & $\begin{array}{l}\text { Dibromochloromethane }\left(\mathrm{CHBr}_{2} \mathrm{Cl}\right) \\
\quad \text { (chlorodibromomethane) }\end{array}$ & 34396 & $67-72-1$ & $\begin{array}{l}\text { 1,1,1,2,2,2-Hexachloroethane }\left(\mathrm{C}_{2} \mathrm{Cl}_{6}\right) \\
\quad \text { (carbon hexachloride) }\end{array}$ \\
\hline 34571 & $106-46-7$ & $\begin{array}{l}\text { 1,4-Dichlorobenzene }\left(\mathrm{C}_{6} \mathrm{H}_{4} \mathrm{Cl}_{2}\right) \\
\text { (p-dichlorobenzene })\end{array}$ & 77223 & $98-82-8$ & $\begin{array}{l}\text { (1-Methylethyl)benzene }\left(\mathrm{C}_{9} \mathrm{H}_{12}\right) \\
\text { (isopropylbenzene) }\end{array}$ \\
\hline 34668 & $75-71-8$ & $\begin{array}{l}\text { Dichlorodifluoromethane }\left(\mathrm{CCl}_{2} \mathrm{~F}_{2}\right) \\
\quad(\mathrm{CFC} 12)\end{array}$ & 34696 & $91-20-3$ & Naphthalene $\left(\mathrm{C}_{10} \mathrm{H}_{8}\right)$ \\
\hline 34496 & $75-34-3$ & $\begin{array}{l}\text { 1,1-Dichloroethane }\left(\mathrm{C}_{2} \mathrm{H}_{4} \mathrm{Cl}_{2}\right) \\
\text { (ethylidene chloride) }\end{array}$ & 81577 & $108-20-3$ & $\begin{array}{l}\text { 2,2'-Oxybis[propane] }\left(\mathrm{C}_{6} \mathrm{H}_{14} \mathrm{O}\right) \\
\text { (diisopropyl ether, DIPE) }\end{array}$ \\
\hline 32103 & $107-06-2$ & $\begin{array}{l}\text { 1,2-Dichloroethane }\left(\mathrm{C}_{2} \mathrm{H}_{4} \mathrm{Cl}_{2}\right) \\
\quad \text { (ethylene dichloride) }\end{array}$ & 34210 & $107-02-8$ & $\begin{array}{l}\text { 2-Propenal }\left(\mathrm{C}_{3} \mathrm{H}_{4} \mathrm{O}\right) \\
\quad \text { (acrolein) }\end{array}$ \\
\hline 34501 & $75-35-4$ & $\begin{array}{l}\text { 1,1-Dichloroethene }\left(\mathrm{C}_{2} \mathrm{H}_{2} \mathrm{Cl}_{2}\right) \\
\quad \text { (vinylidene chloride) }\end{array}$ & 34215 & $107-13-1$ & $\begin{array}{l}\text { 2-Propenenitrile }\left(\mathrm{C}_{3} \mathrm{H}_{3} \mathrm{~N}\right) \\
\quad \text { (acrylonitrile) }\end{array}$ \\
\hline 77093 & $156-59-2$ & $\begin{array}{l}\text { cis-1,2-Dichloroethene }\left(\mathrm{C}_{2} \mathrm{H}_{2} \mathrm{Cl}_{2}\right) \\
\quad((\mathrm{Z}) \text {-1,2-dichloroethene })\end{array}$ & 77224 & $103-65-1$ & $\begin{array}{l}n \text {-Propylbenzene }\left(\mathrm{C}_{9} \mathrm{H}_{12}\right) \\
\quad(1 \text {-phenylpropane })\end{array}$ \\
\hline 34546 & $156-60-5$ & $\begin{array}{l}\text { trans-1,2-Dichloroethene }\left(\mathrm{C}_{2} \mathrm{H}_{2} \mathrm{Cl}_{2}\right) \\
\quad((\mathrm{E})-1,2 \text {-dichloroethene })\end{array}$ & 34475 & $127-18-4$ & $\begin{array}{l}\text { Tetrachloroethene }\left(\mathrm{C}_{2} \mathrm{Cl}_{4}\right) \\
\text { (perchloroethene, } \mathrm{PCE} \text { ) }\end{array}$ \\
\hline 34423 & $75-09-2$ & $\begin{array}{l}\text { Dichloromethane }\left(\mathrm{CH}_{2} \mathrm{Cl}_{2}\right) \\
\text { (methylene chloride) }\end{array}$ & 32102 & $56-23-5$ & $\begin{array}{l}\text { Tetrachloromethane }\left(\mathrm{CCl}_{4}\right) \\
\text { (carbon tetrachloride) }\end{array}$ \\
\hline
\end{tabular}


Table 1. Volatile organic compounds analyzed by the U.S. Geological Survey National Water-Quality Assessment Program-Continued

[Compounds are identified by the following: PCODE, U.S. Geological Survey parameter code; CAS no., Chemical Abstract Services number; IUPAC, International Union of Pure and Applied Chemistry; *, not included in spiking solution]

\begin{tabular}{|c|c|c|c|c|c|}
\hline PCODE & CAS no. & $\begin{array}{l}\text { IUPAC compound name } \\
\text { (chemical formula) (common name(s)) }\end{array}$ & PCODE & CAS no. & $\begin{array}{l}\text { IUPAC compound name } \\
\text { (chemical formula) (common name(s)) }\end{array}$ \\
\hline \multicolumn{6}{|c|}{ Target analytes-Continued } \\
\hline 77652 & $76-13-1$ & $\begin{array}{l}\text { 1,1,2-Trichloro-1,2,2-trifluoroethane } \\
\qquad\left(\mathrm{C}_{2} \mathrm{Cl}_{3} \mathrm{~F}_{3}\right)(\mathrm{CFC} 113)\end{array}$ & 34488 & $75-69-4$ & $\begin{array}{l}\text { Trichlorofluoromethane }\left(\mathrm{CCl}_{3} \mathrm{~F}\right) \\
\quad(\mathrm{CFC} 11)\end{array}$ \\
\hline 34551 & $120-82-1$ & 1,2,4-Trichlorobenzene $\left(\mathrm{C}_{6} \mathrm{H}_{3} \mathrm{Cl}_{3}\right)$ & 77443 & $96-18-4$ & $\begin{array}{l}\text { 1,2,3-Trichloropropane }\left(\mathrm{C}_{3} \mathrm{H}_{5} \mathrm{Cl}_{3}\right) \\
\text { (allyl trichloride) }\end{array}$ \\
\hline 34506 & $71-55-6$ & $\begin{array}{l}\text { 1,1,1-Trichloroethane }\left(\mathrm{C}_{2} \mathrm{H}_{3} \mathrm{Cl}_{3}\right) \\
\text { (methyl chloroform) }\end{array}$ & 77222 & $95-63-6$ & $\begin{array}{l}\text { 1,2,4-Trimethylbenzene }\left(\mathrm{C}_{9} \mathrm{H}_{12}\right) \\
\text { (pseudocumene) }\end{array}$ \\
\hline 81555 & $108-86-1$ & $\begin{array}{l}\text { Bromobenzene }\left(\mathrm{C}_{6} \mathrm{H}_{5} \mathrm{Br} \text { ) }\right. \\
\text { (phenyl bromide) }\end{array}$ & *77103 & $591-78-6$ & $\begin{array}{l}\text { 2-Hexanone }\left(\mathrm{C}_{6} \mathrm{H}_{12} \mathrm{O}\right) \\
\quad \text { (butyl methyl ketone, MBK) }\end{array}$ \\
\hline 77297 & $74-97-5$ & $\begin{array}{l}\text { Bromochloromethane }\left(\mathrm{CH}_{2} \mathrm{BrCl}\right) \\
\text { (methylene chlorobromide) }\end{array}$ & $* 77424$ & $74-88-4$ & $\begin{array}{l}\text { Iodomethane }\left(\mathrm{CH}_{3} \mathrm{I}\right) \\
\text { (methyl iodide) }\end{array}$ \\
\hline *81595 & $78-93-3$ & $\begin{array}{l}\text { 2-Butanone }\left(\mathrm{C}_{4} \mathrm{H}_{8} \mathrm{O}\right) \\
\quad \text { (methyl ethyl ketone, MEK) }\end{array}$ & 77356 & $99-87-6$ & $\begin{array}{l}\text { 1-Isopropyl-4-methylbenzene }\left(\mathrm{C}_{10} \mathrm{H}_{14}\right) \\
\text { ( } p \text {-isopropyltoluene })\end{array}$ \\
\hline *77041 & $75-15-0$ & Carbon disulfide $\left(\mathrm{CS}_{2}\right)$ & $* 81597$ & $80-62-6$ & $\begin{array}{l}\text { Methyl 2-methyl-2-propenoate }\left(\mathrm{C}_{5} \mathrm{H}_{8} \mathrm{O}_{2}\right) \\
\text { (methyl methacrylate) }\end{array}$ \\
\hline 77275 & $95-49-8$ & $\begin{array}{l}\text { 1-Chloro-2-methylbenzene }\left(\mathrm{C}_{7} \mathrm{H}_{7} \mathrm{Cl}\right) \\
\text { (o-chlorotoluene) }\end{array}$ & *78133 & $108-10-1$ & $\begin{array}{l}\text { 4-Methyl-2-pentanone }\left(\mathrm{C}_{6} \mathrm{H}_{12} \mathrm{O}\right) \\
\text { (isobutyl methyl ketone, MIK) }\end{array}$ \\
\hline 73547 & $110-57-6$ & $\begin{array}{l}\text { trans-1,4-Dichloro-2-butene }\left(\mathrm{C}_{4} \mathrm{H}_{6} \mathrm{Cl}_{2}\right) \\
\quad((\mathrm{E}) \text {-1,4-dichloro-2-butene })\end{array}$ & 81576 & $60-29-7$ & $\begin{array}{l}\text { 1,1'-Oxybisethane }\left(\mathrm{C}_{4} \mathrm{H}_{10} \mathrm{O}\right) \\
\quad \text { (diethyl ether) }\end{array}$ \\
\hline 77173 & $142-28-9$ & $\begin{array}{l}\text { 1,3-Dichloropropane }\left(\mathrm{C}_{3} \mathrm{H}_{6} \mathrm{Cl}_{2}\right) \\
\quad \text { (trimethylene dichloride) }\end{array}$ & *81552 & $67-64-1$ & $\begin{array}{l}\text { 2-Propanone }\left(\mathrm{C}_{3} \mathrm{H}_{6} \mathrm{O}\right) \\
\quad \text { (acetone) }\end{array}$ \\
\hline 77170 & 594-20-7 & 2,2-Dichloropropane $\left(\mathrm{C}_{3} \mathrm{H}_{6} \mathrm{Cl}_{2}\right)$ & 77562 & $630-20-6$ & 1,1,1,2-Tetrachloroethane $\left(\mathrm{C}_{2} \mathrm{H}_{2} \mathrm{Cl}_{4}\right)$ \\
\hline 77168 & $563-58-6$ & 1,1-Dichloropropene $\left(\mathrm{C}_{3} \mathrm{H}_{4} \mathrm{Cl}_{2}\right)$ & 34516 & $79-34-5$ & 1,1,2,2-Tetrachloroethane $\left(\mathrm{C}_{2} \mathrm{H}_{2} \mathrm{Cl}_{4}\right)$ \\
\hline 77353 & $98-06-6$ & $\begin{array}{l}\text { (1,1-Dimethylethyl)benzene }\left(\mathrm{C}_{10} \mathrm{H}_{14}\right) \\
\text { (tert-butylbenzene) }\end{array}$ & 49999 & $488-23-3$ & $\begin{array}{l}\text { 1,2,3,4-Tetramethylbenzene }\left(\mathrm{C}_{10} \mathrm{H}_{14}\right) \\
\quad \text { (prehitene) }\end{array}$ \\
\hline$* 81607$ & $109-99-9$ & $\begin{array}{l}\text { 1,4-Epoxybutane }\left(\mathrm{C}_{4} \mathrm{H}_{8} \mathrm{O}\right) \\
\quad \text { (tetrahydrofuran) }\end{array}$ & 50000 & $527-53-7$ & $\begin{array}{l}\text { 1,2,3,5-Tetramethylbenzene }\left(\mathrm{C}_{10} \mathrm{H}_{14}\right) \\
\quad \text { (isodurene) }\end{array}$ \\
\hline 77220 & $611-14-3$ & $\begin{array}{l}\text { 1-Ethyl-2-methylbenzene }\left(\mathrm{C}_{9} \mathrm{H}_{12}\right) \\
\text { (2-ethyltoluene) }\end{array}$ & 77221 & $526-73-8$ & $\begin{array}{l}\text { 1,2,3-Trimethylbenzene }\left(\mathrm{C}_{9} \mathrm{H}_{12}\right) \\
\text { (hemimellitene) }\end{array}$ \\
\hline *73570 & $97-63-2$ & $\begin{array}{l}\text { Ethyl 2-methyl-2-propenoate }\left(\mathrm{C}_{6} \mathrm{H}_{10} \mathrm{O}_{2}\right) \\
\quad \text { (ethyl methacrylate) }\end{array}$ & 77226 & $108-67-8$ & $\begin{array}{l}\text { 1,3,5-Trimethylbenzene }\left(\mathrm{C}_{9} \mathrm{H}_{12}\right) \\
\text { (mesitylene) }\end{array}$ \\
\hline
\end{tabular}


consisted of an initial canister blank and an initial equipment blank. A source-solution blank was not collected. The initial canister blank was collected to determine if the canister, from which the equipment blank was collected, was contaminated with VOCs. The initial equipment blank was collected to characterize the condition of the VOC point sampler prior to collection of field samples. Blanks were collected according to methods described by Mueller and others (1997).

Seven concurrent samples were collected near midstream using both the VOC point sampler and by hand dipping a VOA vial in the stream. The VOC point sampler was cleaned between each replicate sample. After all replicate samples were collected, the samplers were cleaned again and a final canister and a final equipment blank were collected with the VOC point sampler.

\section{ANALYTICAL AND STATISTICAL RESULTS}

Results of the replicate analyses for laboratory and field testing are listed in table 2 . Results of qualitycontrol samples are listed in table 3 at the end of this report. If a concentration is preceded by a less than $(<)$ symbol, the compound was not detected in the sample. If a concentration is preceded by an "E," the compound was detected in the sample but its concentration was estimated (Connor and others, 1998). For statistical purposes, estimated concentrations were considered the same as non-estimated concentrations.

Table 2 lists the percent relative standard deviation (\% RSD) among replicates for each sampler as well as the statistically determined two-sided p-value. The \% RSD is a measure of reproducibility. If the $\%$ RSD is low $(<10 \%)$, similarity between replicates is high. Percent RSD was only calculated for laboratory testing because the concentration of the solution being sampled remained constant. The two-sided p-value was determined using the sign test to compare the replicates between the VOC point sampler and either the glass-siphon (laboratory) or hand-dipping (field) method. The sign test is nonparametric and is used to test for differences between two populations. For this study, the null hypothesis is that there is no systematic difference between samples collected using the VOC point sampler and either the glass-siphon or handdipping method. For a confidence level of 95 percent, this hypothesis would be rejected at p-values less than 0.025 and accepted at $p$-values greater than or equal to 0.025 . Thus, as p-values increase, there is increasing confidence that there is no systematic difference between samples collected using the VOC point sampler and either of the other two methods.

The \% RSD values in table 2 are relatively small, with 57 of 73 calculated values for \% RSD less than 10 for the VOC point sampler, representing a high degree of reproducibility. This compares well to 56 of 72 calculated values for \% RSD less than 10 for the glasssiphon sampler. The two-sided p-values in table 2 show that sample results do not vary between the VOC point sampler and either glass siphoning in the laboratory study or hand dipping in the field for most VOCs. As seen in table 2, 98 of $101 \mathrm{p}$-values are greater than 0.025 (95\% confidence interval), which indicates little difference between sampling methods.

Data were plotted to visually compare results of the VOC point sampler, the glass-siphon method (laboratory), and the hand-dipping method (field).

Figure 2 illustrates the laboratory comparisons, and figure 3 illustrates the field comparisons. The figures show the VOC point sampler performed well in comparison to the other two sampling methods. Some scatter is visible at lower concentrations and could be due to analytical procedures in the laboratory, effects of the sampler, or possibly both.

From figure 2, it can be seen that analyte loss is very minimal. Concentrations of approximately $0.3 \mu \mathrm{g} / \mathrm{L}$ was spiked for 59 compounds. Fifteen VOCs were spiked to achieve a concentration of approximately $1.2 \mu \mathrm{g} / \mathrm{L}$ and trans-1,4-dichloro-2-butene was spiked to $3.0 \mu \mathrm{g} / \mathrm{L}$. These concentrations can be seen in figure 2 at concentrations similar to those that were initially spiked. Clusters of data can be seen at $0.3,1.2$, and $3 \mu \mathrm{g} / \mathrm{L}$. The values at approximately $10 \mu \mathrm{g} / \mathrm{L}$ are for the compound 2-propanone, a possible contaminant in the spiking solution.

The quality-control samples (table 3 ) show that decontamination protocols are adequate to fully clean the VOC point sampler. Detected concentrations of select compounds were traced back to the source solution, and not considered to be contamination by the VOC point sampler, canister, or cleaning protocols. Specifically, two VOCs, trichloromethane (chloroform) and 2-propanone, were present in the source solution and detected in all quality-control samples. Three other random detections were found in the quality-control blanks. Chlorobenzene and 1,1,2,3,4, 4-hexachloro-1,3-butadiene were detected in the initial canister blank in the laboratory, but these compounds were not detected in the associated equipment blank. A low concentration $(\mathrm{E} 0.03 \mu \mathrm{g} / \mathrm{L})$ of 2-butanone was detected in the high-concentration equipment blank. 


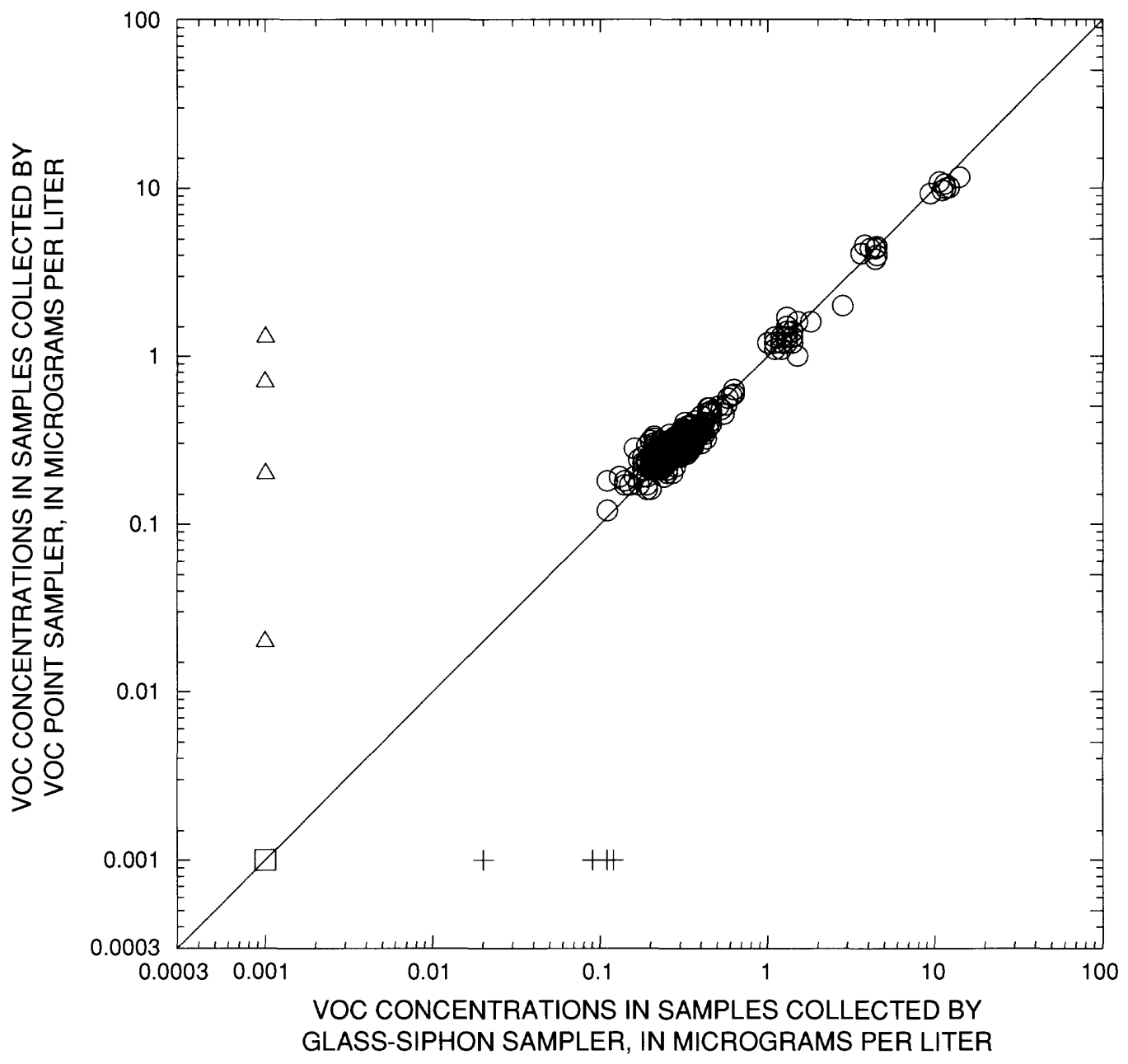

EXPLANATION

\begin{tabular}{|c|c|}
\hline & $1: 1$ LINE \\
\hline 0 & $\begin{array}{l}\text { DETECTED IN SAMPLES COLLECTED BY VOC POINT SAMPLER AND GLASS-SIPHON } \\
\text { SAMPLER (512 PAIRS) }\end{array}$ \\
\hline$\square$ & $\begin{array}{l}\text { NOT DETECTED IN SAMPLES COLLECTED BY EITHER VOC POINT SAMPLER OR } \\
\text { GLASS-SIPHON SAMPLER (80 PAIRS) }\end{array}$ \\
\hline$\triangle$ & $\begin{array}{l}\text { DETECTED IN SAMPLES COLLECTED BY VOC POINT SAMPLER AND NOT DETECTED } \\
\text { IN SAMPLES COLLECTED BY GLASS-SIPHON SAMPLER (4 PAIRS) }\end{array}$ \\
\hline+ & NOT DETECTED IN SAMPLES COLLECTED BY VOC POINT SAMPLER AND DETECTED \\
\hline
\end{tabular}

Figure 2. Graphical comparison of concentrations of 87 volatile organic compounds (VOCs) in samples collected by VOC point sampler with concentrations in samples collected by glass-siphon sampler during laboratory testing. 


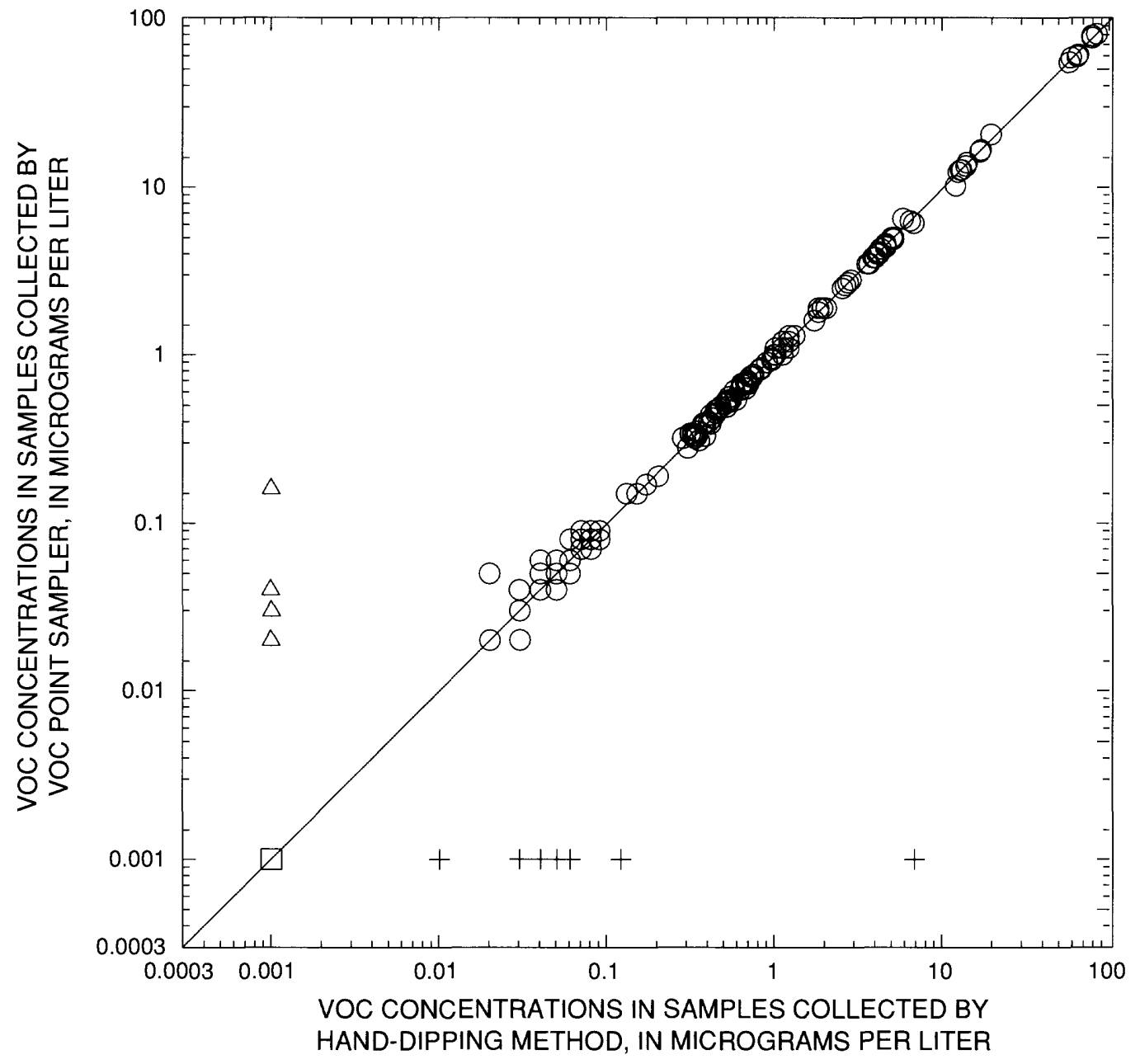

EXPLANATION

1:1 LINE

DETECTED IN SAMPLES COLLECTED BY VOC POINT SAMPLER AND HAND-DIPPING METHOD (168 PAIRS)

NOT DETECTED IN SAMPLES COLLECTED BY EITHER VOC POINT SAMPLER OR HAND-DIPPING METHOD (419 PAIRS)

$\triangle \quad$ DETECTED IN SAMPLES COLLECTED BY VOC POINT SAMPLER AND NOT DETECTED IN SAMPLES COLLECTED BY HAND-DIPPING METHOD (8 PAIRS)

$+\quad$ NOT DETECTED IN SAMPLES COLLECTED BY VOC POINT SAMPLER AND DETECTED IN SAMPLES COLLECTED BY HAND-DIPPING METHOD (7 PAIRS)

Figure 3. Graphical comparison of concentrations of 87 volatile organic compounds (VOCs) in samples collected by VOC point sampler with concentrations in samples collected by hand-dipping method during field testing. 


\section{REFERENCES CITED}

Connor, B.F., Rose, D.L., Noriega, M.C., Murtagh, L.K., and Abney, S.R., 1998, Methods of analysis by the U.S. Geological Survey National Water-Quality Laboratory-Determination of 86 volatile organic compounds in water by gas chromatography/mass spectrometry, including detections less than reporting limits: U.S. Geological Survey Open-File Report 97-829, 78 p.

Helsel, D.R., and Hirsch, R.M., 1992, Statistical methods in water resources: New York, Elsevier Science Publishing Company, Inc., 522 p.
Lopes, T.J., and Price, C.V., 1997, Study plan for urban stream indicator sites of the National Water-Quality Assessment Program: U.S. Geological Survey OpenFile Report 97-25, 15 p.

Mueller, D.K, Martin, J.D., and Lopes, T.J., 1997, Qualitycontrol design for surface-water sampling in the National Water-Quality Assessment Program: U.S. Geological Survey Open-File Report 97-223, 17 p.

Shelton, L.R., 1997, Field guide for collecting samples for analysis of volatile organic compounds in stream water for the National Water-Quality Assessment Program: U.S. Geological Survey Open-File Report 97-401, 14 p. 
TABLES 2 and 3 
12 


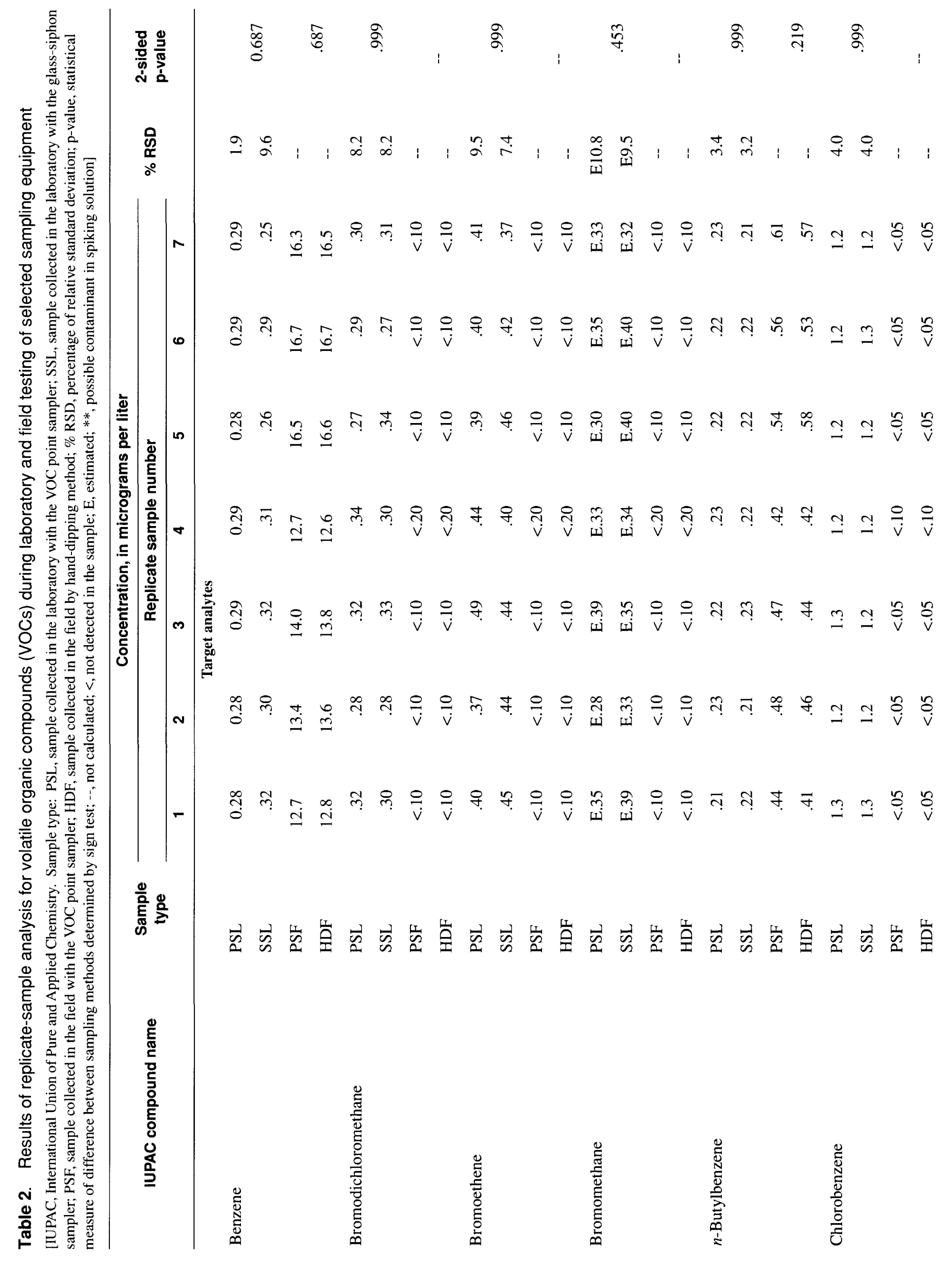




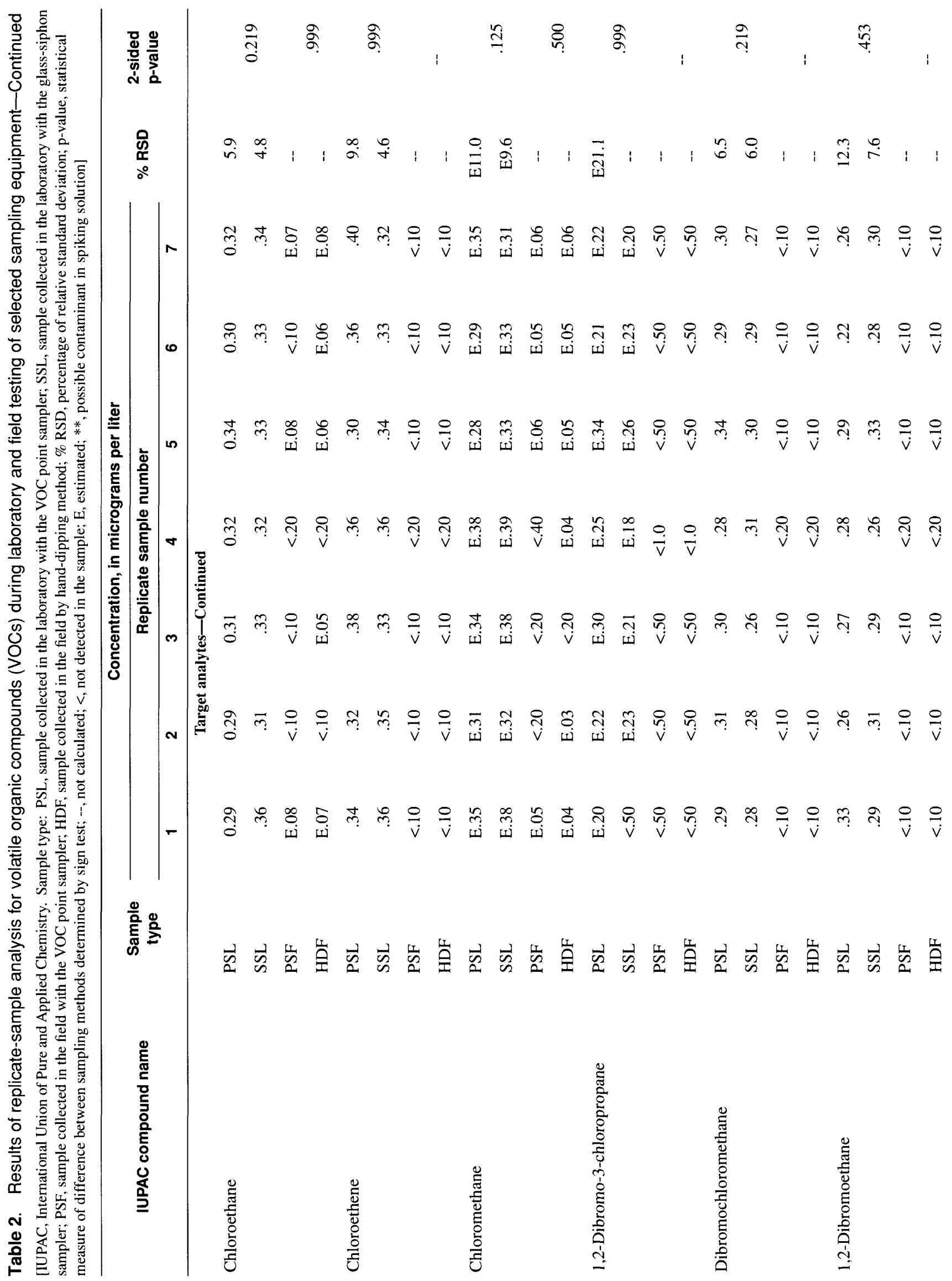




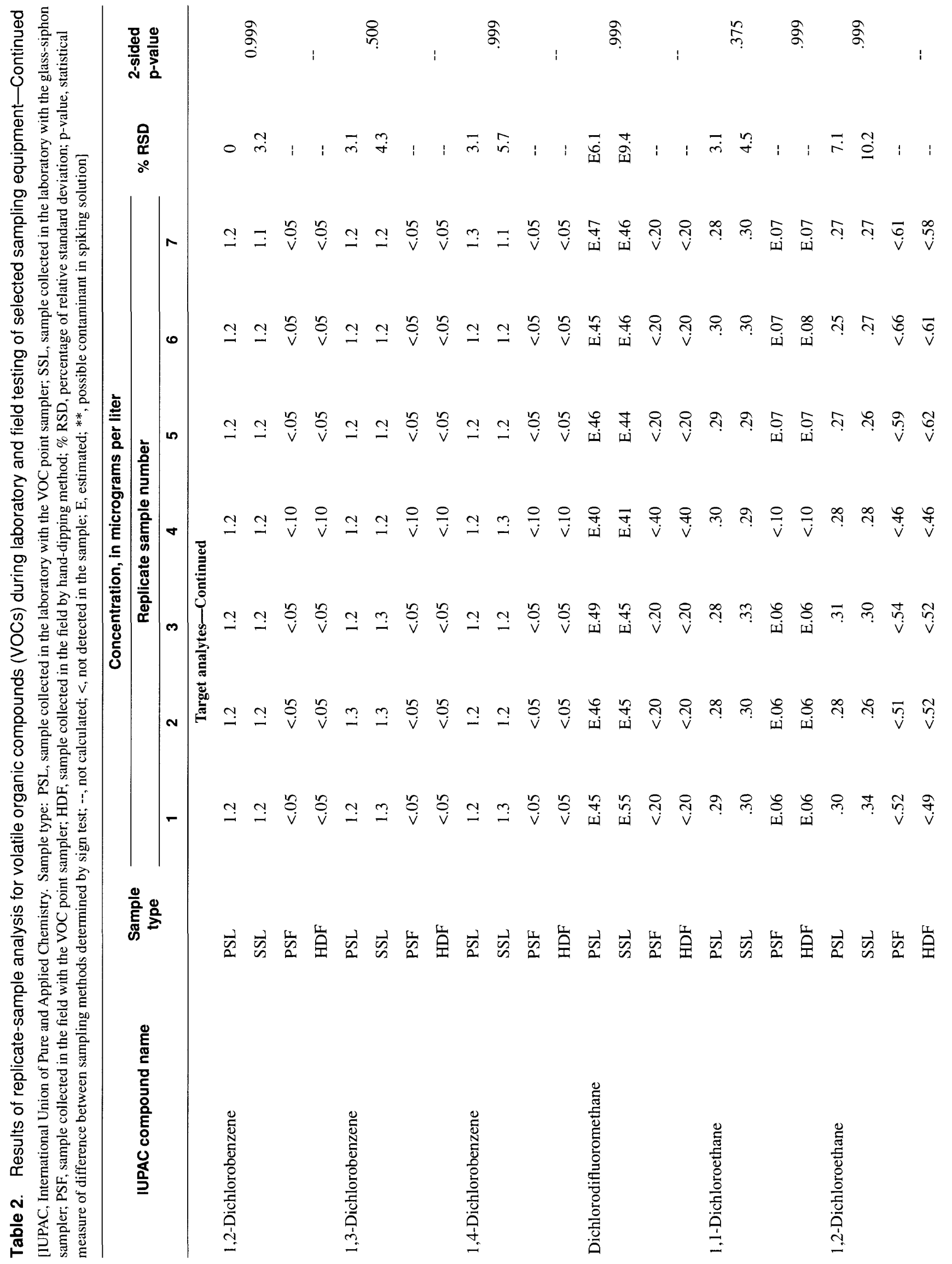




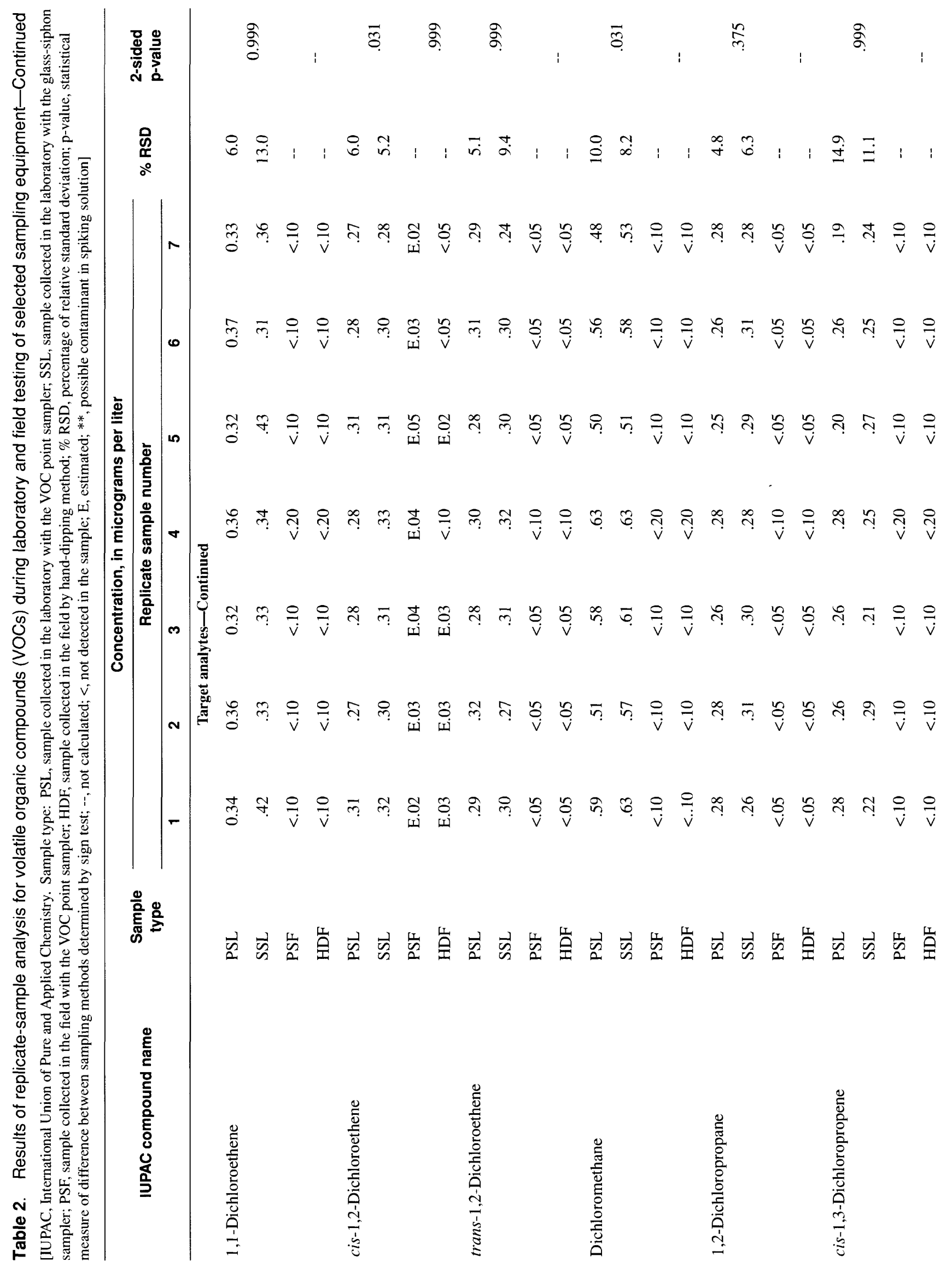




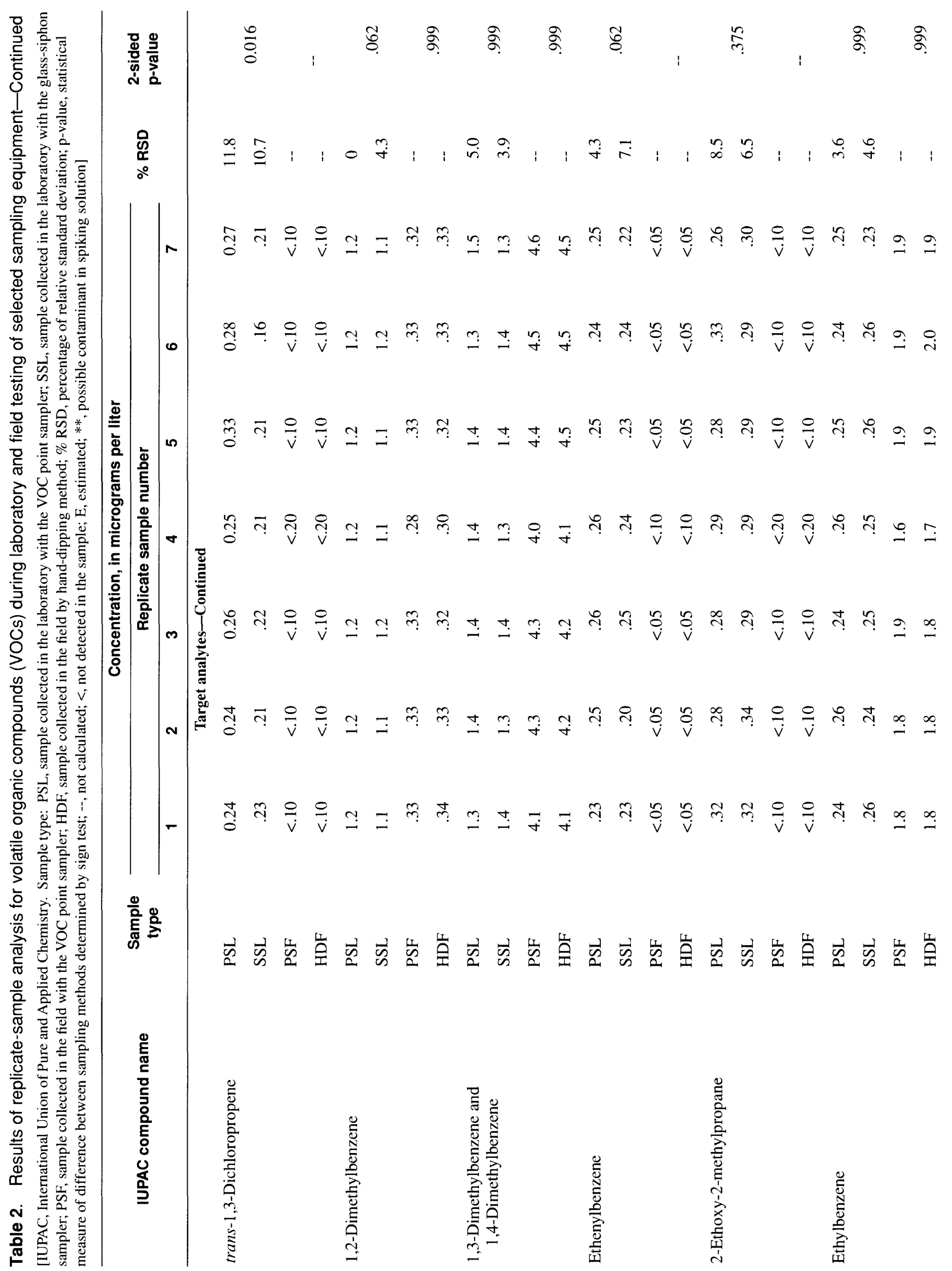

Table 217 


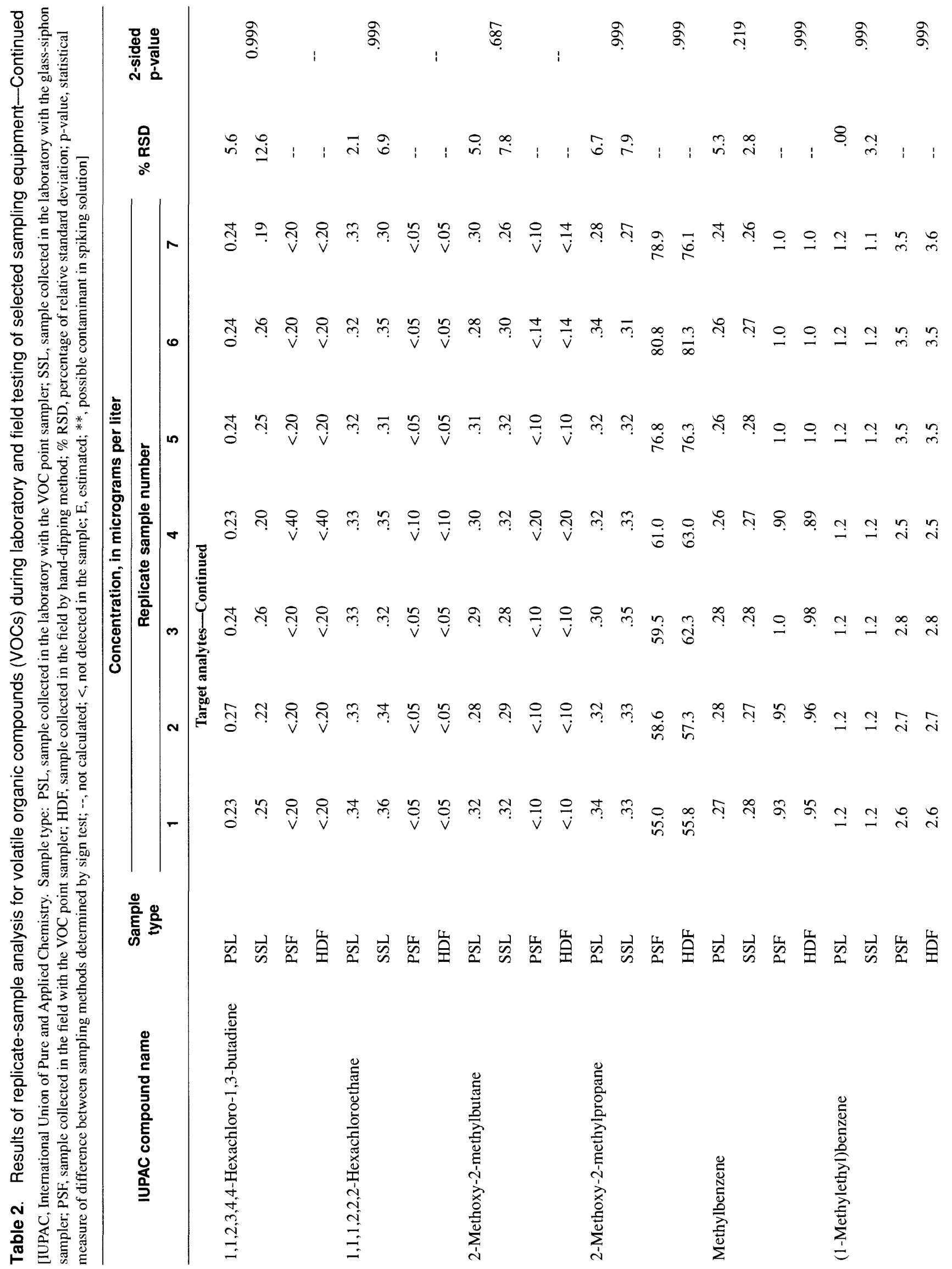




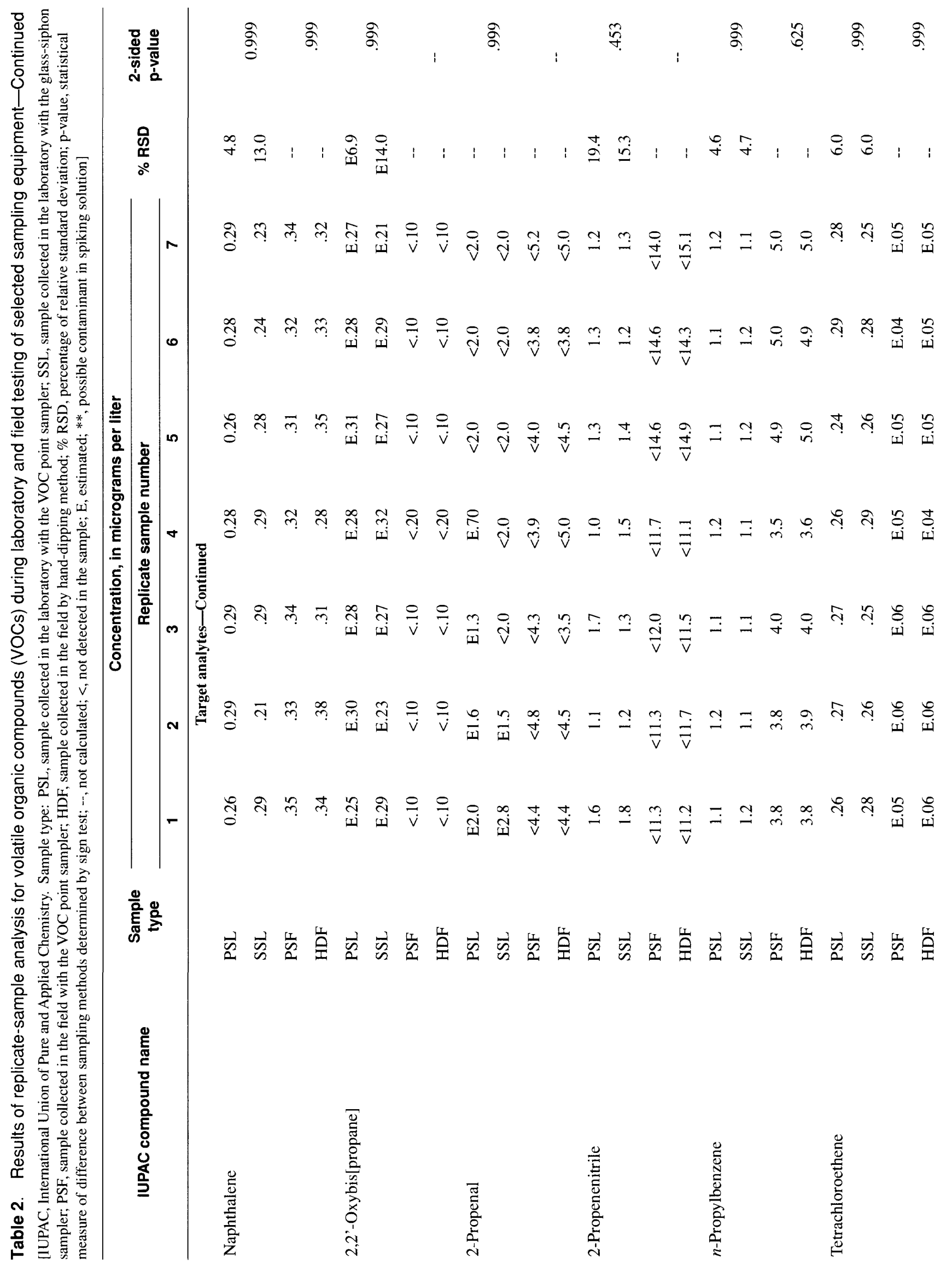




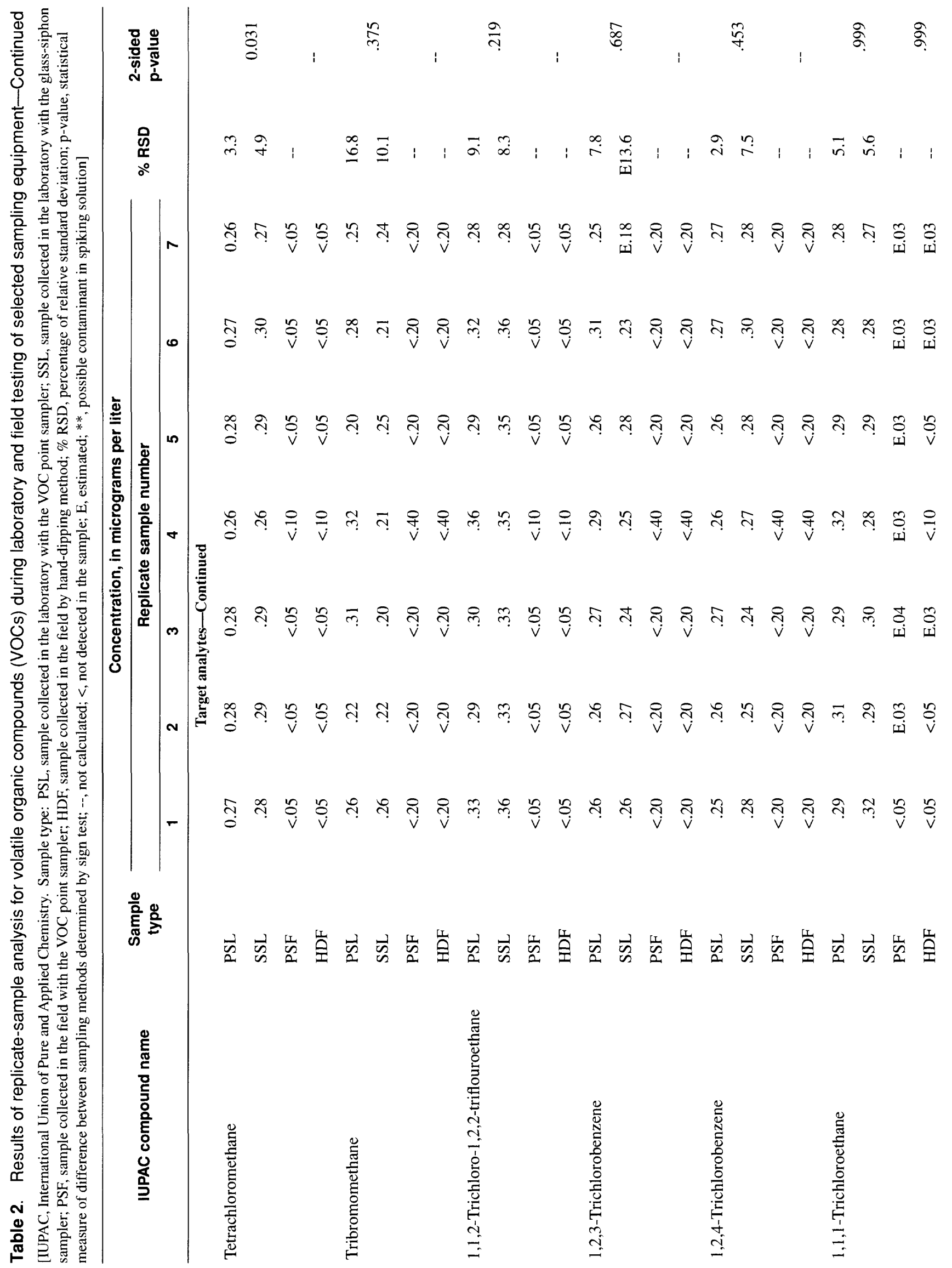




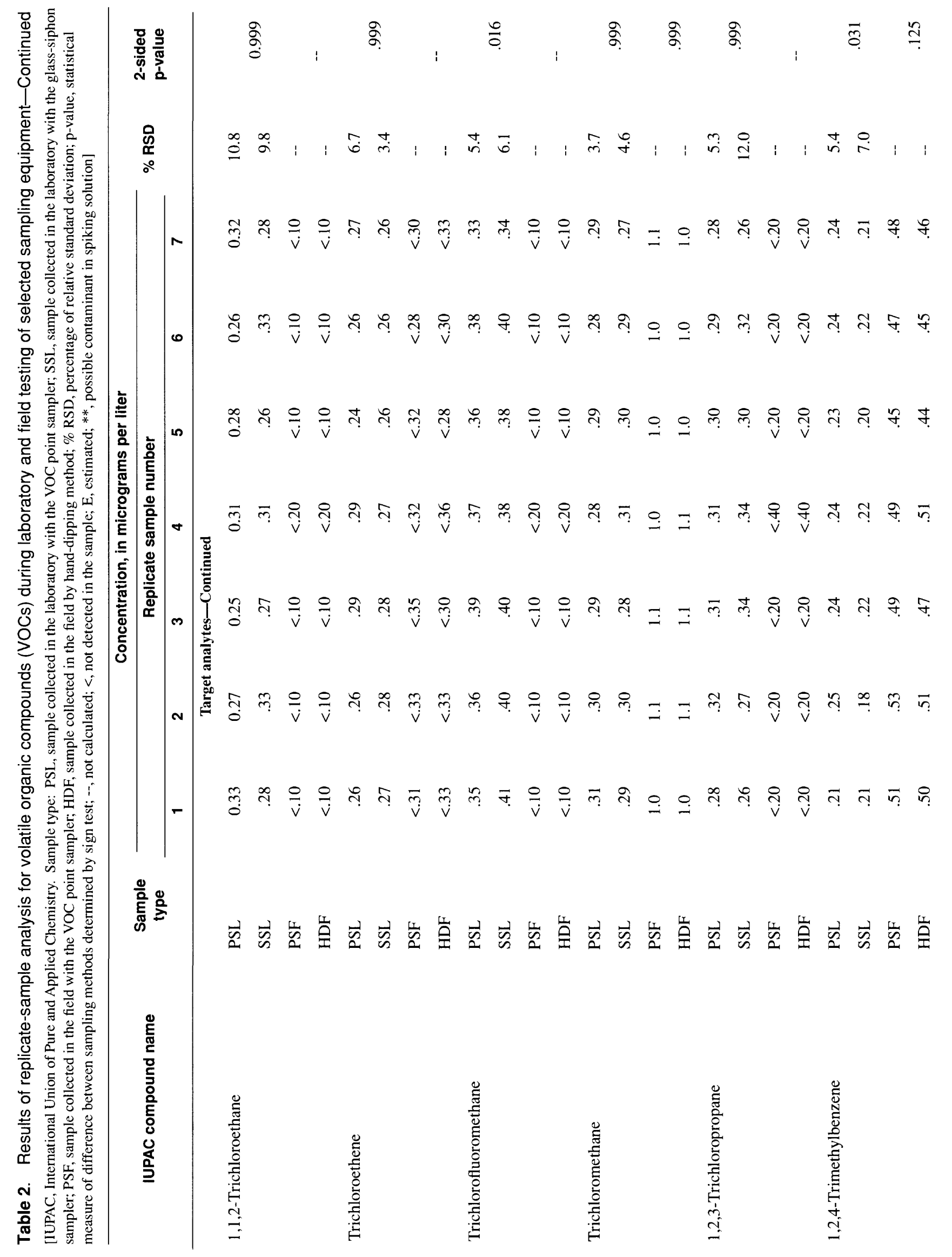




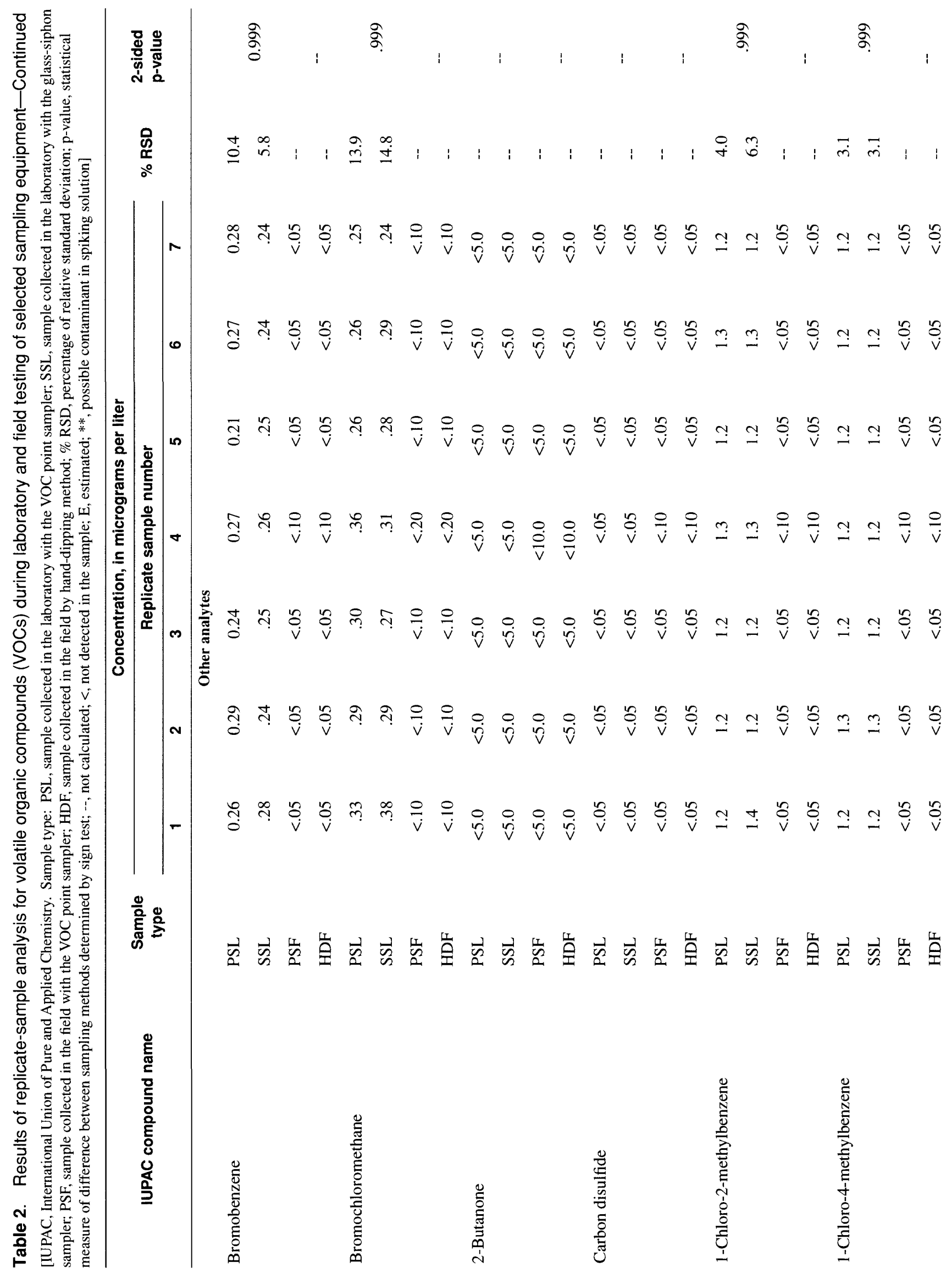




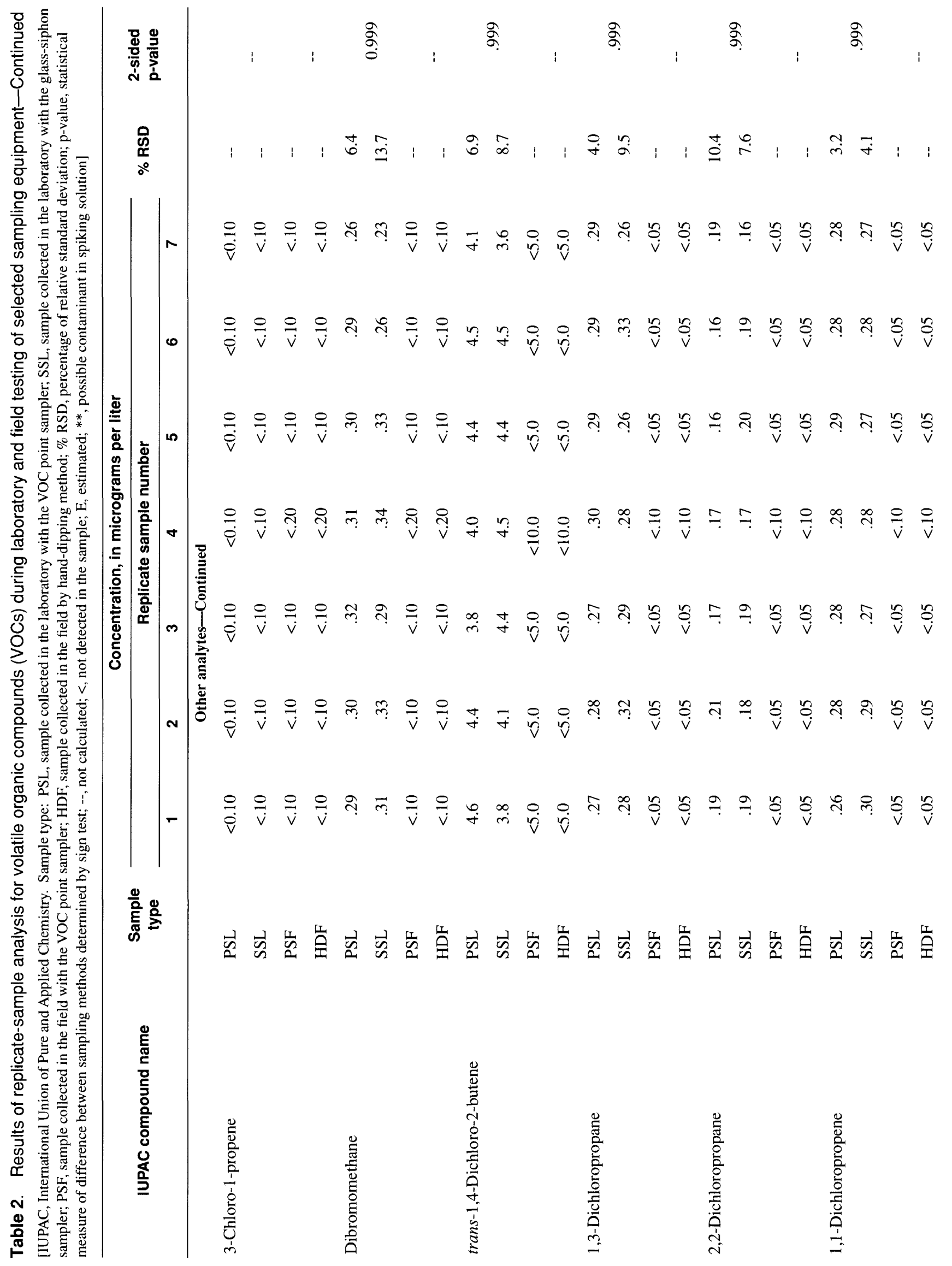




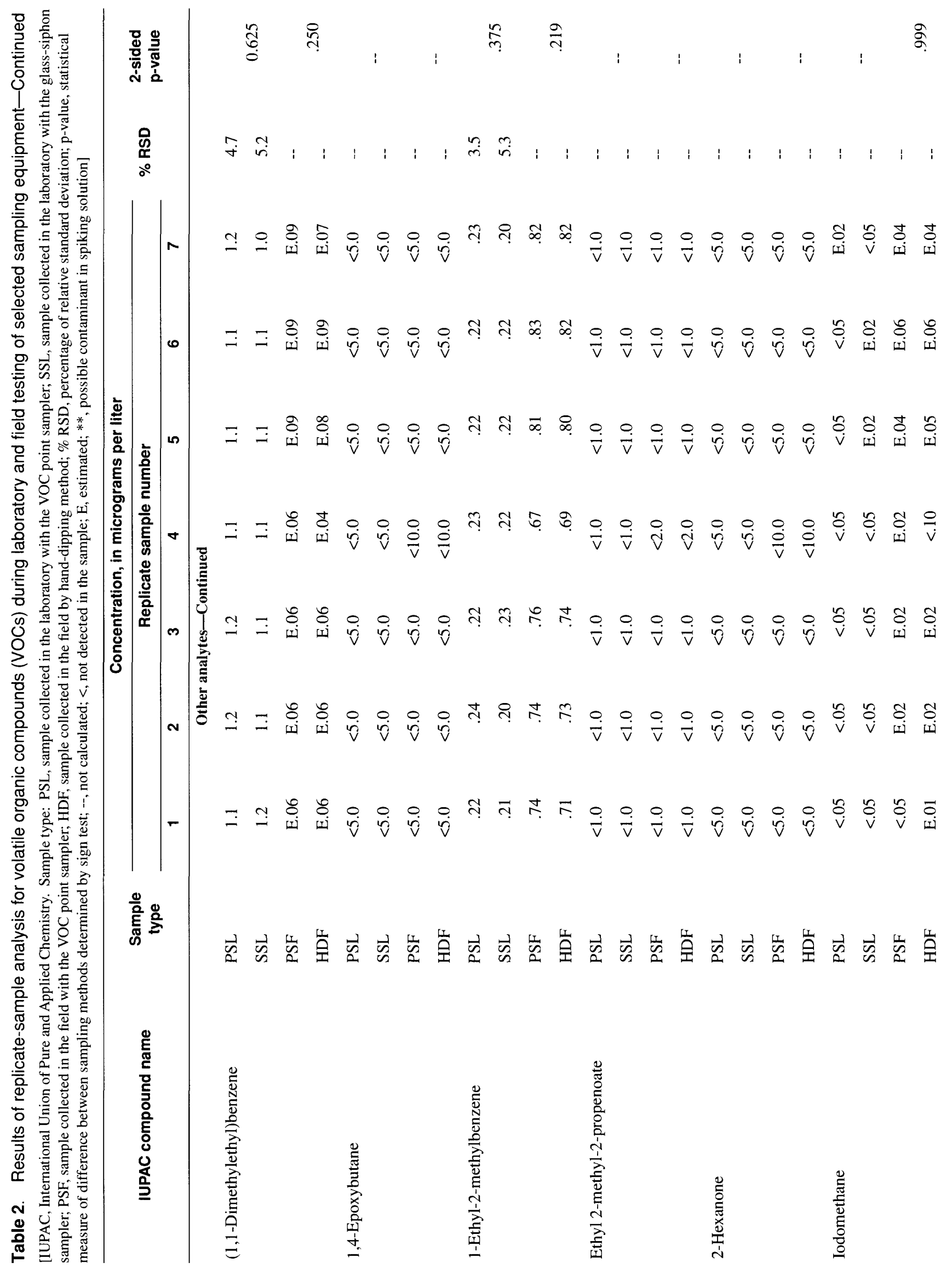




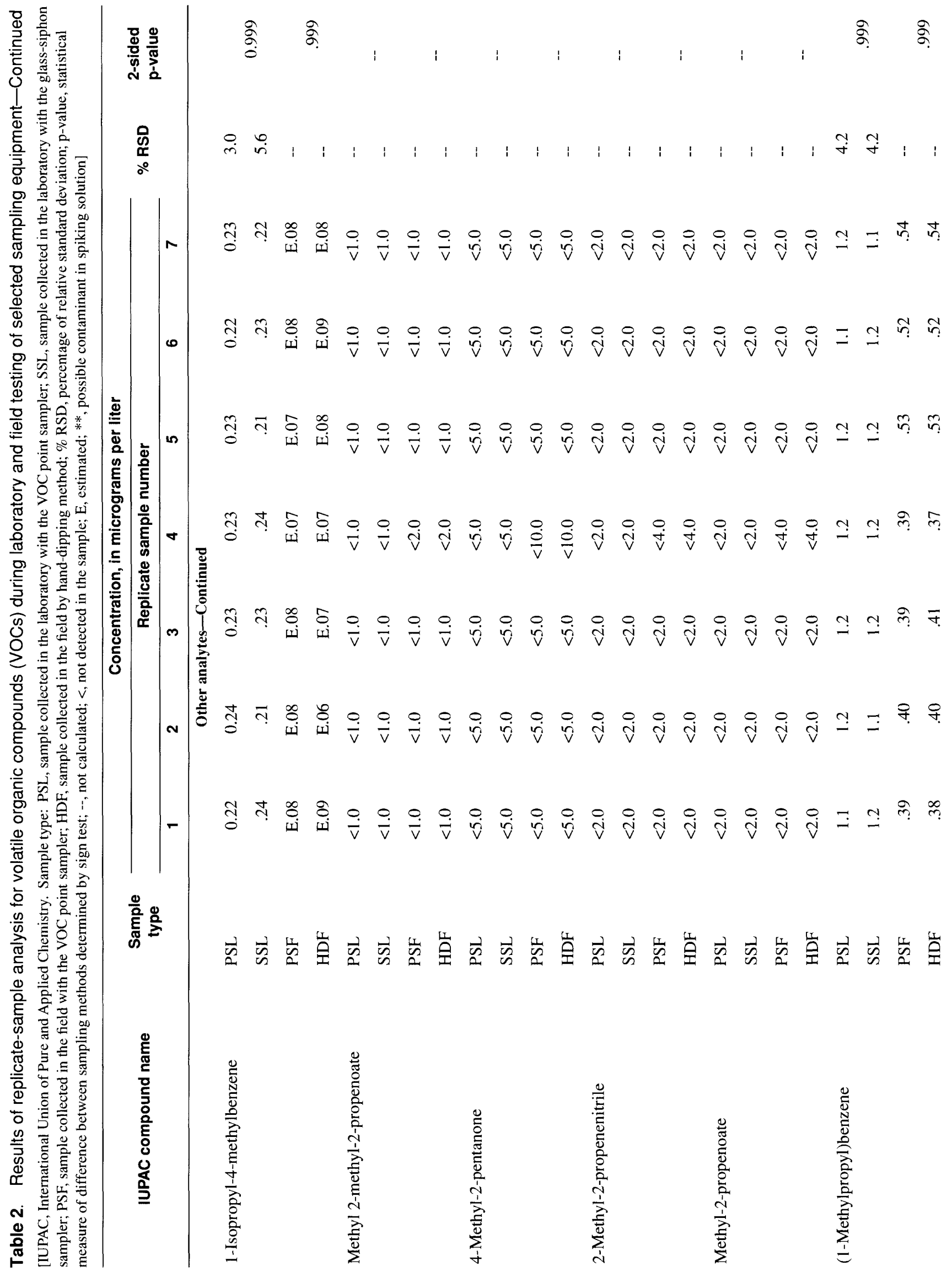




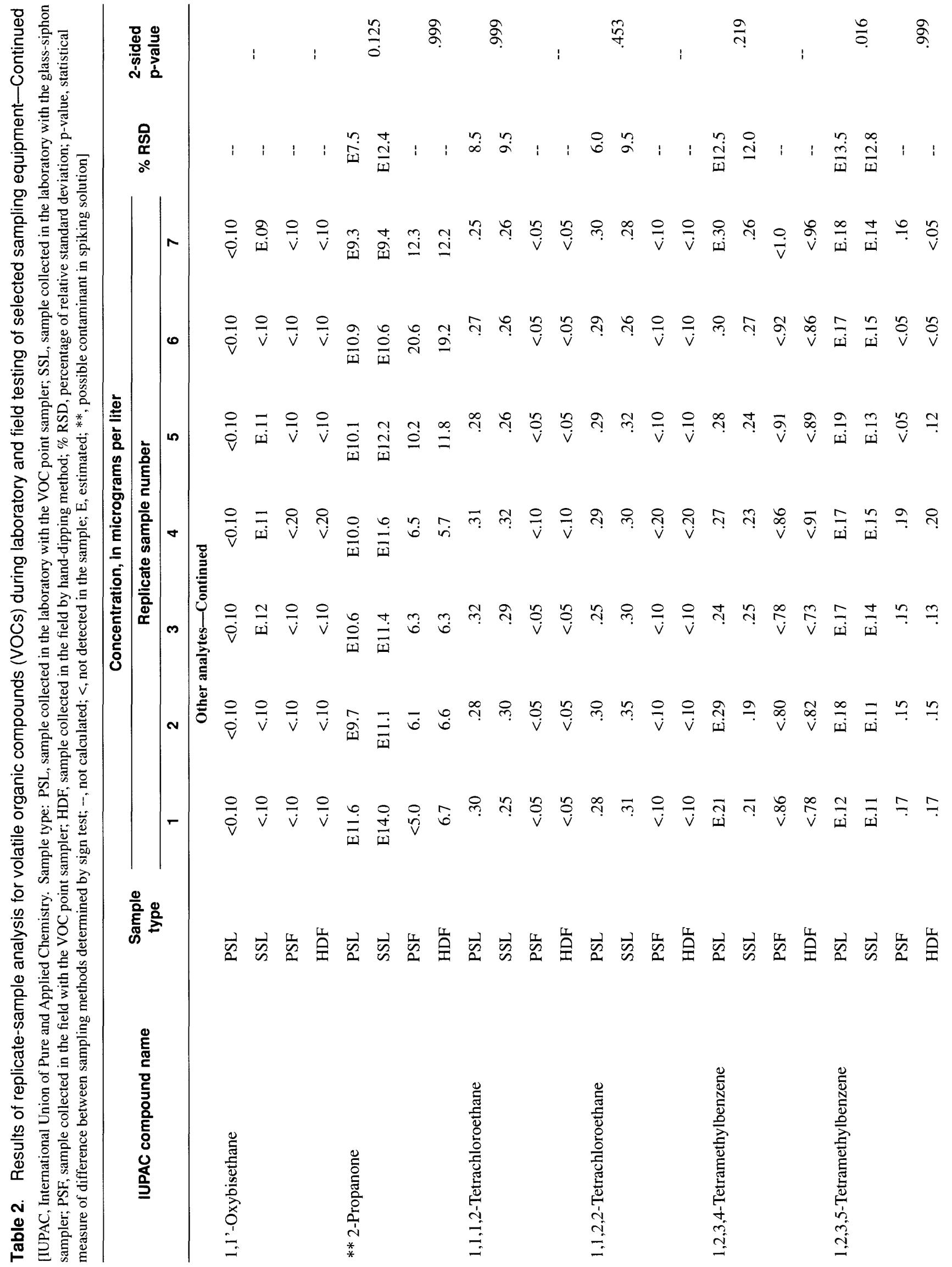




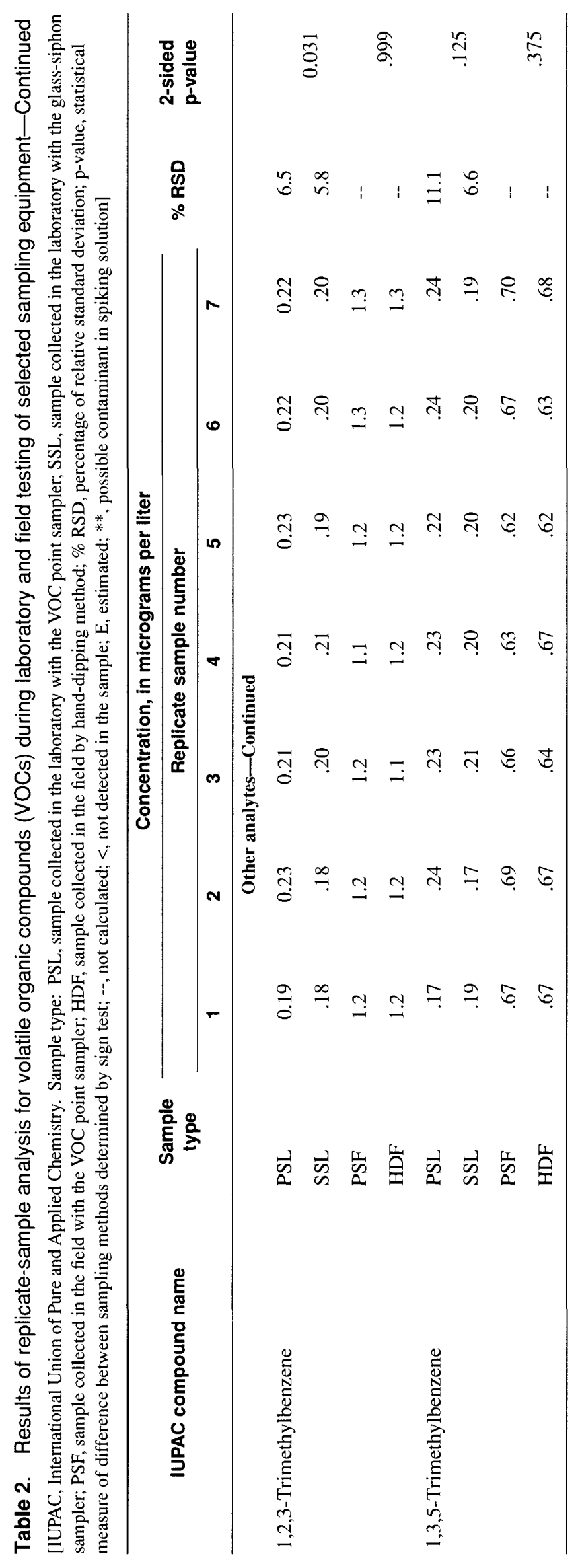




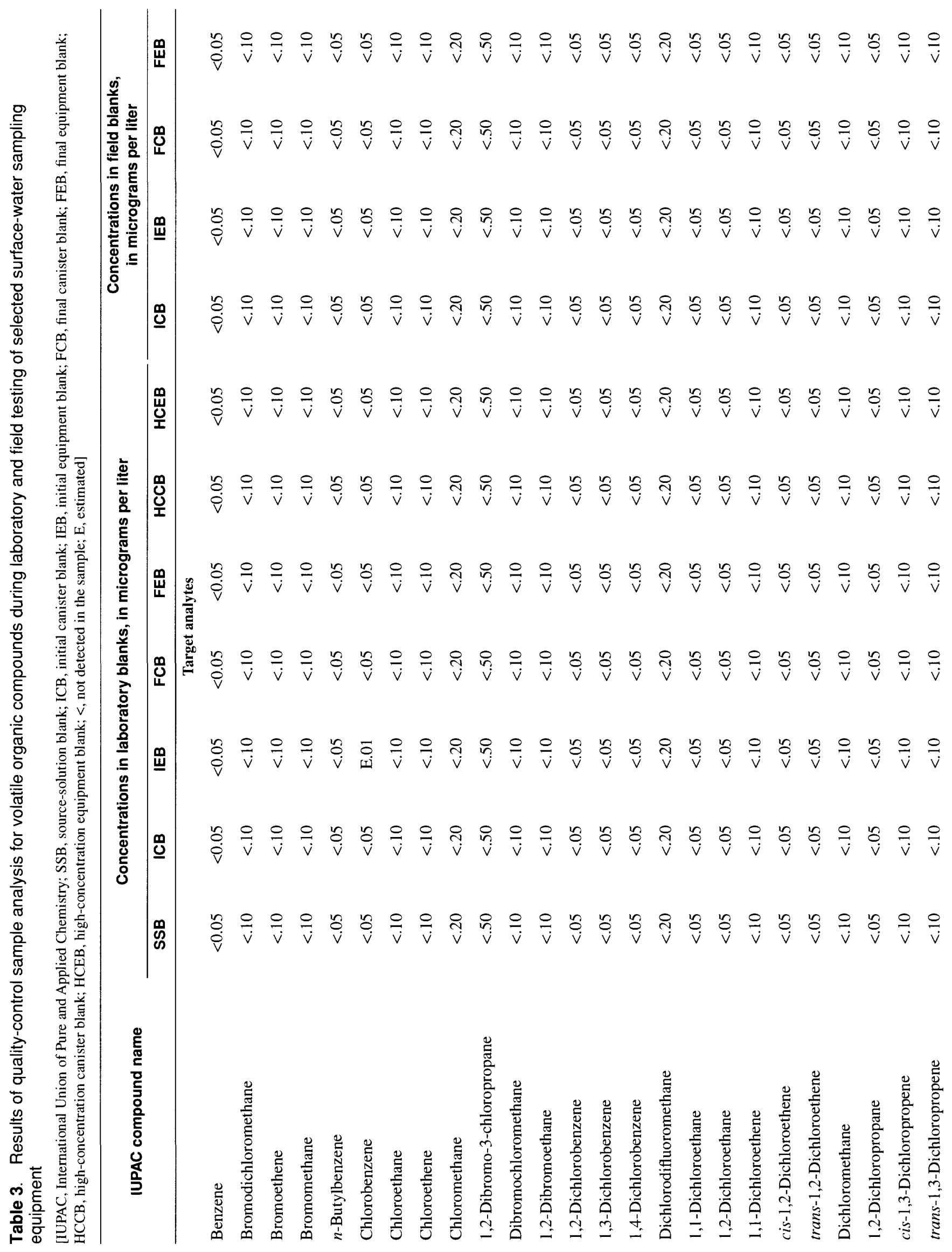




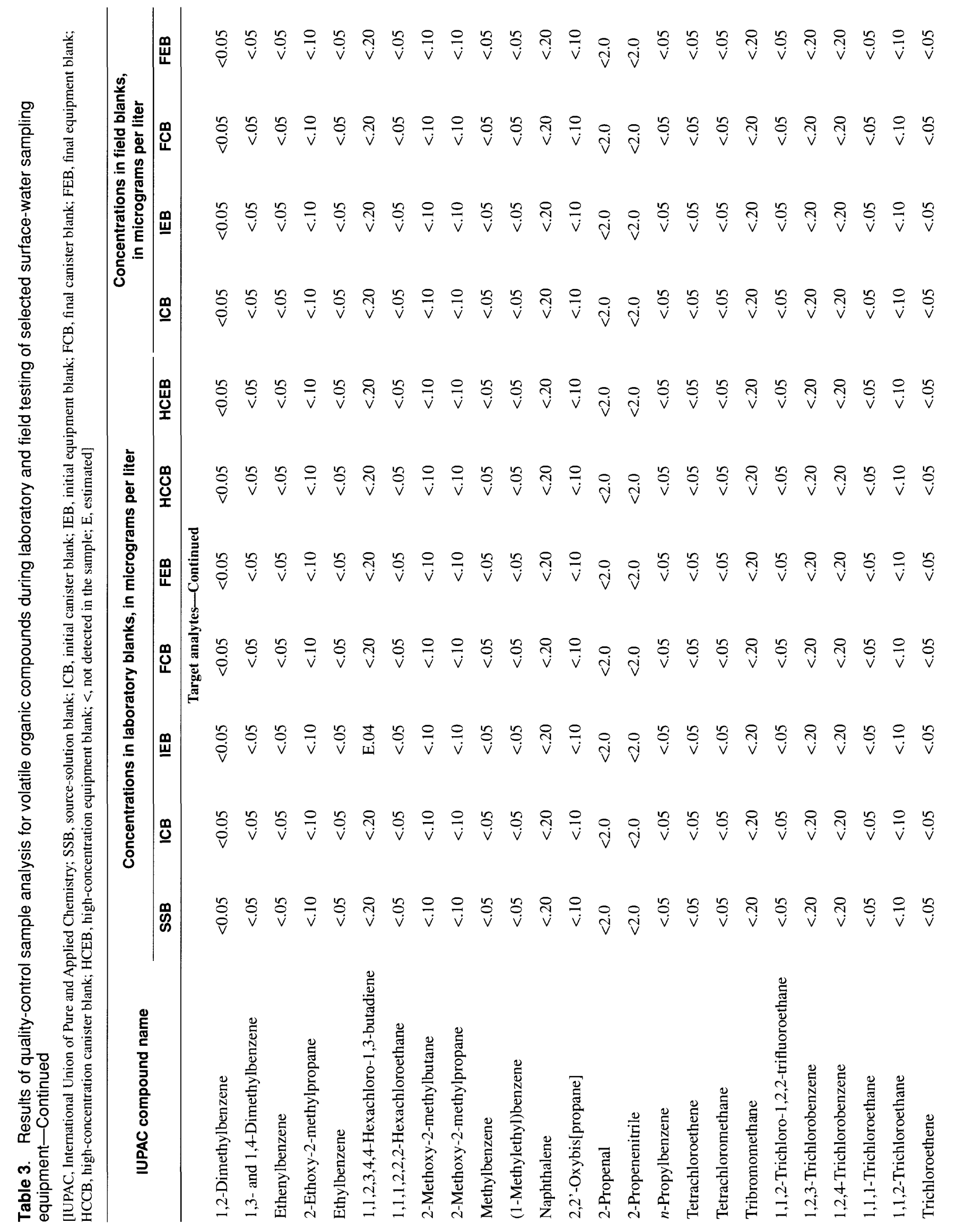




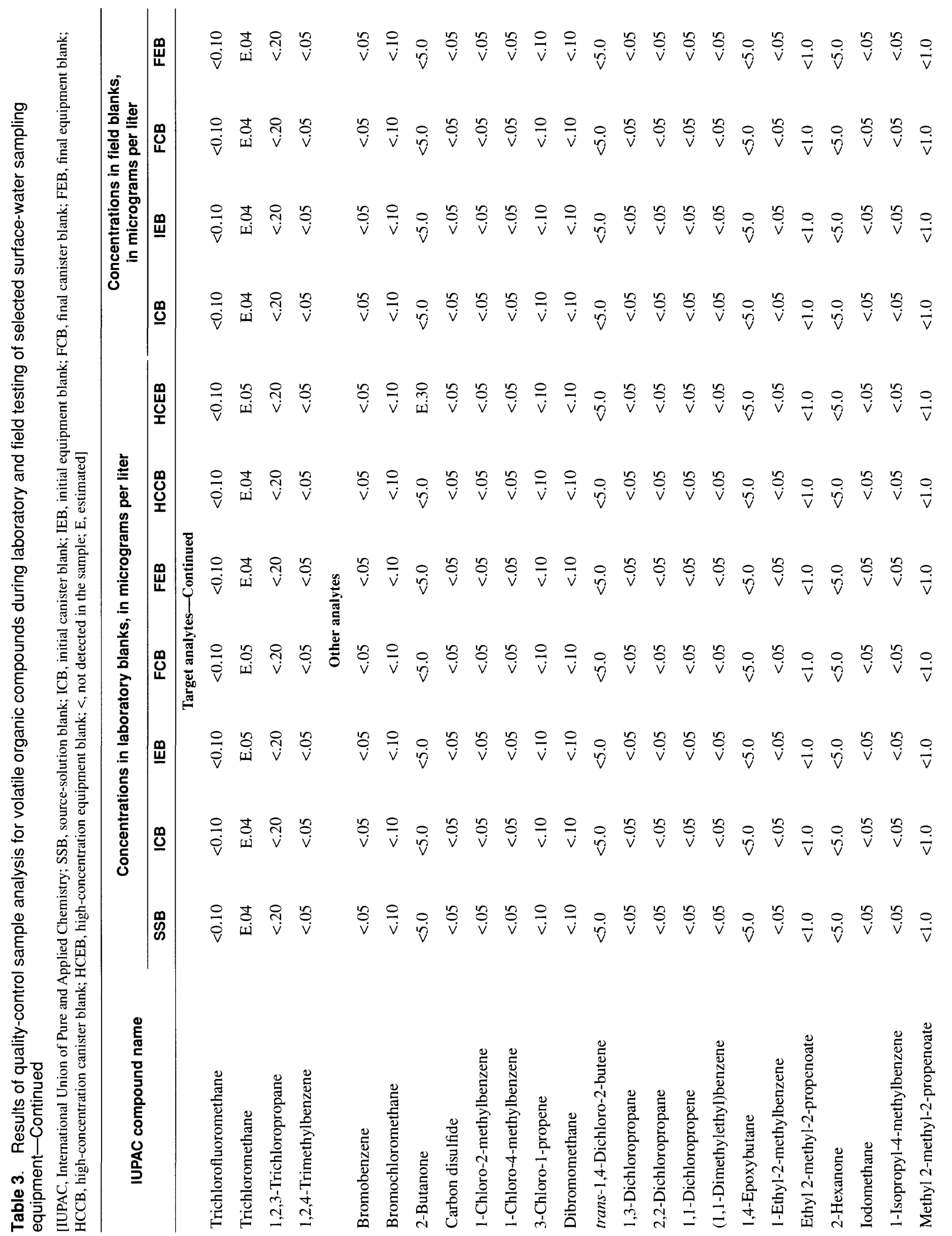




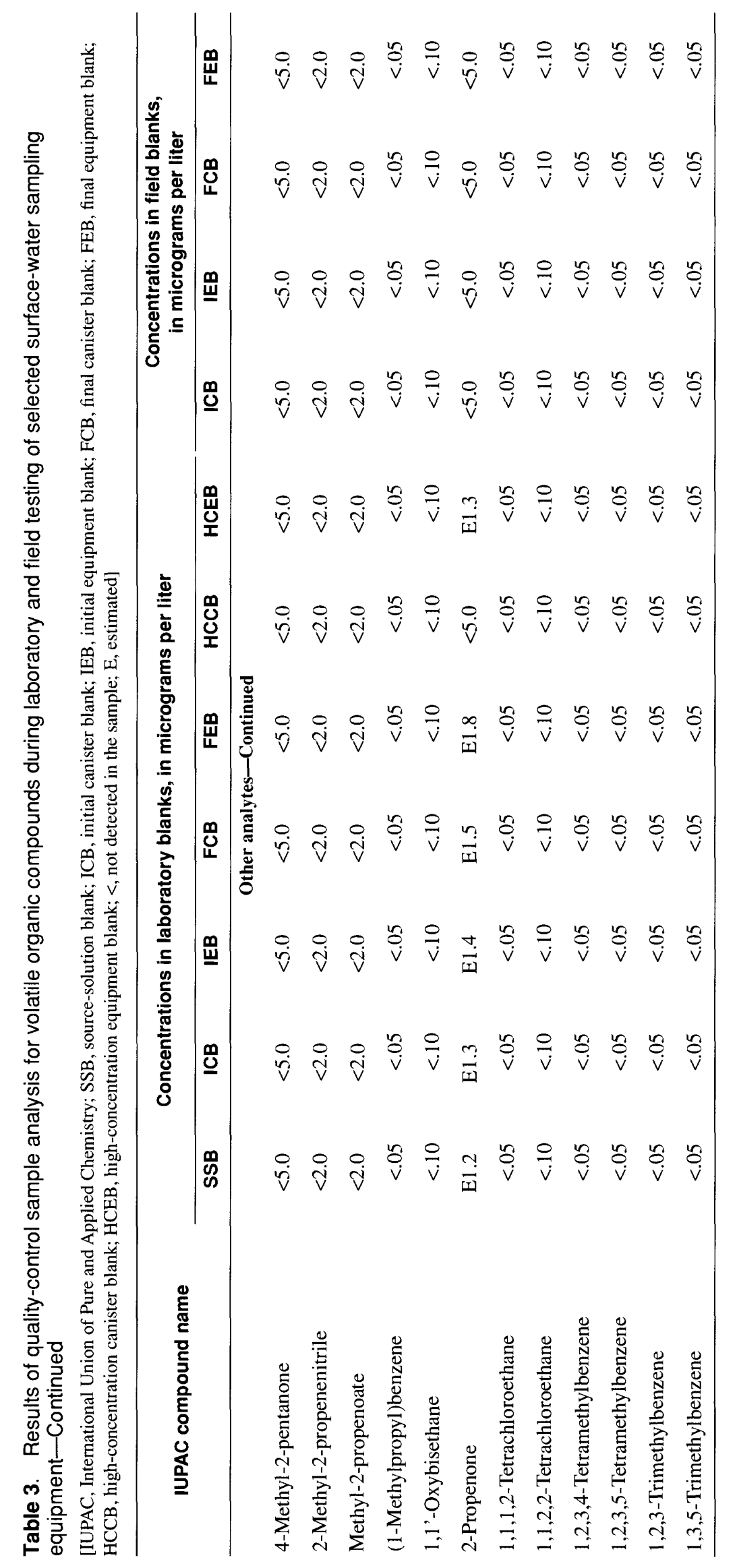

Table 331 